\title{
RESEARCH
}

Open Access

\section{Hospital utilization rates for influenza and RSV: a novel approach and critical assessment}

Emily K. Johnson 1* (D, Dillon Sylte ${ }^{1}$, Sandra S. Chaves ${ }^{2,3}$, You Li ${ }^{4}$, Cedric Mahe ${ }^{2,3}$, Harish Nair ${ }^{4}$, John Paget ${ }^{5}$, Tayma van Pomeren ${ }^{5}$, Ting Shi ${ }^{4}$, Cecile Viboud ${ }^{6}$ and Spencer L. James ${ }^{1}$

\begin{abstract}
Background: Influenza and respiratory syncytial virus (RSV) contribute significantly to the burden of acute lower respiratory infection (ALRI) inpatient care, but heterogeneous coding practices and availability of inpatient data make it difficult to estimate global hospital utilization for either disease based on coded diagnoses alone.

Methods: This study estimates rates of influenza and RSV hospitalization by calculating the proportion of ALRI due to influenza and RSV and applying this proportion to inpatient admissions with ALRI coded as primary diagnosis. Proportions of ALRI attributed to influenza and RSV were extracted from a meta-analysis of 360 total sources describing inpatient hospital admissions which were input to a Bayesian mixed effects model over age with random effects over location. Results of this model were applied to inpatient admission datasets for 44 countries to produce rates of hospital utilization for influenza and RSV respectively, and rates were compared to raw coded admissions for each disease.

Results: For most age groups, these methods estimated a higher national admission rate than the rate of directly coded influenza or RSV admissions in the same inpatient sources. In many inpatient sources, International Classification of Disease (ICD) coding detail was insufficient to estimate RSV burden directly. The influenza inpatient burden estimates in older adults appear to be substantially underestimated using this method on primary diagnoses alone. Application of the mixed effects model reduced heterogeneity between countries in influenza and RSV which was biased by coding practices and between-country variation.

Conclusions: This new method presents the opportunity of estimating hospital utilization rates for influenza and RSV using a wide range of clinical databases. Estimates generally seem promising for influenza and RSV associated hospitalization, but influenza estimates from primary diagnosis seem highly underestimated among older adults. Considerable heterogeneity remains between countries in ALRI coding (i.e., primary vs non-primary cause), and in the age profile of proportion positive for influenza and RSV across studies. While this analysis is interesting because of its wide data utilization and applicability in locations without laboratory-confirmed admission data, understanding the sources of variability and data quality will be essential in future applications of these methods.
\end{abstract}

Keywords: Influenza, Respiratory syncytial virus, Acute lower respiratory infections, Inpatient admissions

\footnotetext{
*Correspondence: ekj15@uw.edu

'Institute of Health Metrics and Evaluation, University of Washington, Seattle, USA

Full list of author information is available at the end of the article
}

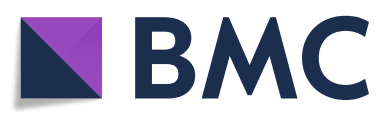

(c) The Author(s). 2021 Open Access This article is licensed under a Creative Commons Attribution 4.0 International License, which permits use, sharing, adaptation, distribution and reproduction in any medium or format, as long as you give appropriate credit to the original author(s) and the source, provide a link to the Creative Commons licence, and indicate if changes were made. The images or other third party material in this article are included in the article's Creative Commons licence, unless indicated otherwise in a credit line to the material. If material is not included in the article's Creative Commons licence and your intended use is not permitted by statutory regulation or exceeds the permitted use, you will need to obtain permission directly from the copyright holder. To view a copy of this licence, visit http://creativecommons.org/licenses/by/4.0/ The Creative Commons Public Domain Dedication waiver (http://creativecommons.org/publicdomain/zero/1.0/) applies to the data made available in this article, unless otherwise stated in a credit line to the data. 


\section{Background}

Despite the large burden of lower respiratory infections globally [1], it is difficult to estimate the proportion of the hospitalizations attributable to influenza and respiratory syncytial virus (RSV) across countries or over time. Heterogeneous coding practices in hospital records across countries limit the comparability of administrative datasets from different locations and pose a challenge to producing global hospitalization estimates using influenza and RSV-coded inpatient admissions alone. Without the addition of laboratory test result data, administrative data may not accurately estimate inpatient disease burden, further complicating efforts to model burden at the population level. Absent accurate population estimates of the burden of specific respiratory diseases, it will be challenging to conduct crosscountry comparison, a hallmark of linking health policies (e.g., masking, vaccination campaigns) to outcomes.

The Burden of Influenza and RSV Disease (BIRD) project has developed an alternative method that may be useful for producing estimates of county-specific influenza and RSV burdens using administrative hospitalization data. This method generates rates of influenza and RSV-related acute lower respiratory illness (ALRI) hospitalizations across 44 countries by modeling the proportion of ALRI hospitalizations specifically attributable to RSV and influenza from literature estimates of laboratory-confirmed influenza and RSV among ALRI hospitalizations. The model can be applied to administrative data on country-specific influenza and RSV utilization. By comparing the results of the BIRD project method to those produced by raw extraction of ICD-coded RSV and influenza admission rates, we can estimate the potential under-attribution of ALRI to these specific causes.

\section{Methods}

At a high level, this study estimates influenza and RSV admission rates by modeling the proportion of ALRI admissions that are due to influenza and RSV respectively, and then multiplying these proportions by ALRI admission rates from clinical administrative data. Figure 1 below is a detailed flowchart of the processing steps used in this analysis, and each step is described in further detail in the following sections.

\section{ALRI admissions calculation}

We extracted admission counts for ALRI from 29 inpatient all-cause admission datasets covering 44 countries and containing hospitalizations spanning the years 1990 to 2017, stratified by age in years or age groups depending on the source. These datasets included approximately 43 million admissions and represent all ICDcoded inpatient admission data used in the Global Burden of Disease Study, an international collaborative study led by the Institute for Health Metrics and Evaluation (IHME) at the University of Washington and supported by over 4800 researchers in more than 140

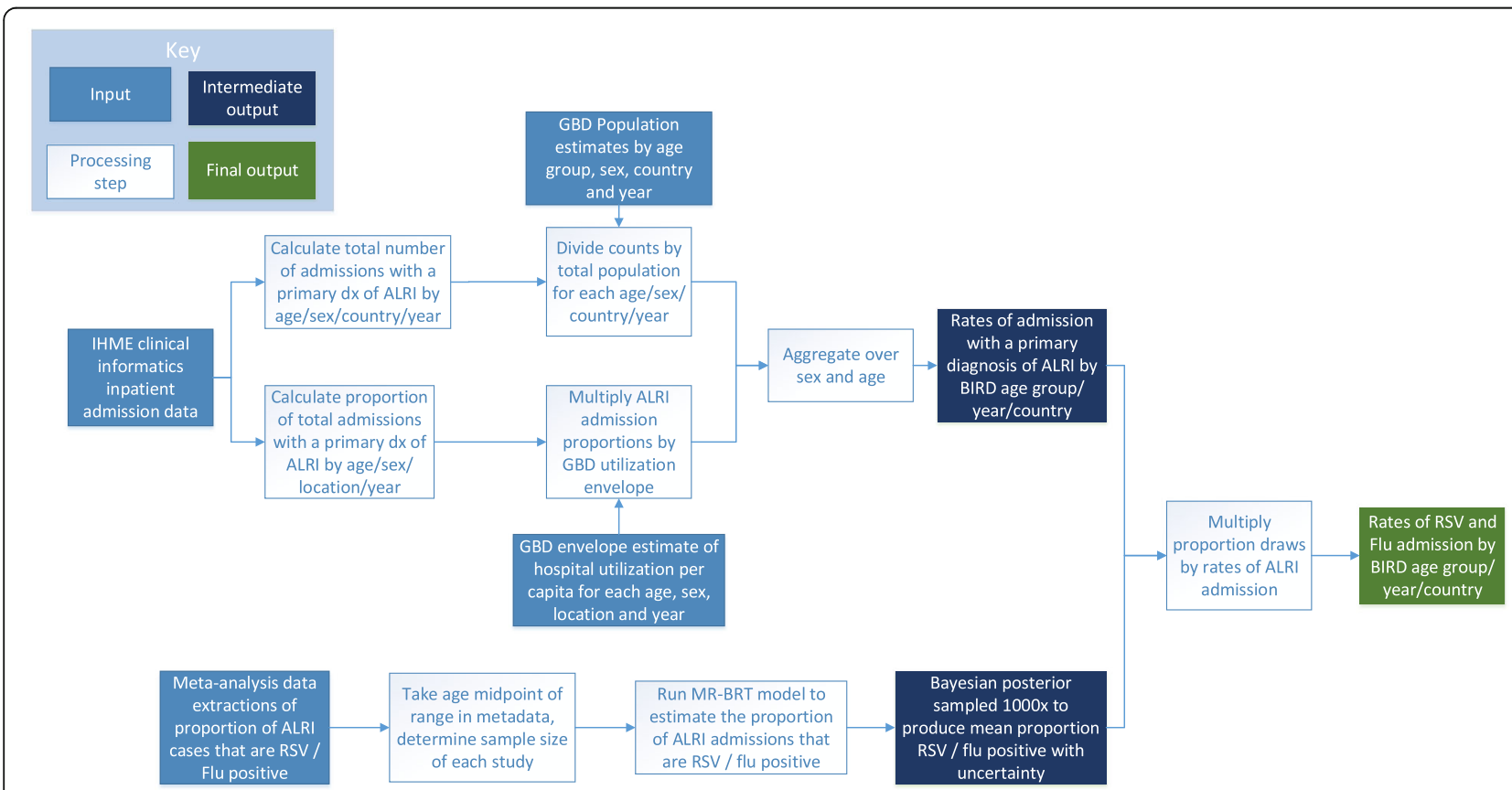

Fig. 1 Flowchart of ALRI admission processing and meta-analysis modeling. Flowchart of data processing and analysis conducted under this study. This diagram describes processing of ALRI admissions from clinical administrative data as well as the modeling and processing performed on RSV and Influenza meta-analysis proportions 
countries [1]. Additional detail on inpatient data from IHME is listed in Additional file 1. Because only 11 of the 44 datasets utilized in this study recorded secondary diagnoses, ALRI admissions were defined as those with a primary diagnosis code listed in Table 1 below.

The majority of clinical datasets in this analysis contain a subset of the country's total inpatient utilization. For these non-comprehensive clinical sources, counts of ALRI admissions by age were divided by the total number of admissions in the dataset to produce age-specific proportions of inpatient utilization that have a primary ALRI diagnosis. This proportion is multiplied by IHME's total inpatient utilization envelope to approximate a comprehensive rate of ALRI utilization by age and country. The envelope is produced using a spatio-temporal Gaussian process regression that smooths over geographic distance and year of hospitalization and that models admission rate per capita by age using IHME's healthcare access quality indicator, supply of inpatient hospital beds, and all-cause mortality as predictive covariates. More detail on the envelope estimation process, covariates used in the model, and results can be found in related Global Burden of Disease (GBD) publications [1].

The UK Hospital Episode Statistics dataset [2] and Healthcare Cost and Utilization Project National
Inpatient Sample (HCUP NIS) [3] are considered comprehensive datasets and the scaling described above was not applied to these sources. Instead, counts of admissions with a primary ALRI diagnosis in these sources were divided by the total population of that country to produce rates of ALRI admission by BIRD age group and year. Population estimates are produced as part of IHME's GBD study and detailed information on the methods to produce these estimates are available in related publications [1].

Most clinical administrative data is provided in age in years or occasionally in various aggregated age bins. The age groupings used for the BIRD analysis were at a higher level of aggregation than the majority of administrative sources used. Therefore, the final step in ALRI admission processing was to aggregate rate-space estimates to the BIRD analysis age groups, by summing both the numerator and denominator so that the rates of ALRI utilization are binned appropriately to match the rest of the analysis.

While many of the data sources used in this analysis are also used in creating annual GBD estimates, there were some differences in data processing methods between the two projects that led to different estimates of rates of ALRI. GBD analysis adjusts inpatient data to

Table 1 Acute lower respiratory infection ICD codes

\begin{tabular}{|c|c|c|}
\hline ICD Version & Code & Description \\
\hline ICD-10 & $\mathrm{J10}$ & Influenza due to identified seasonal influenza virus \\
\hline ICD-10 & $\mathrm{J} 11$ & Influenza, virus not identified \\
\hline ICD-10 & $\mathrm{J} 12$ & Viral pneumonia, not elsewhere classified \\
\hline ICD-10 & $\mathrm{J13}$ & Pneumonia due to Streptococcus pneumoniae \\
\hline ICD-10 & $J 14$ & Pneumonia due to Haemophilus influenzae \\
\hline ICD-10 & J15 & Bacterial pneumonia, not elsewhere classified \\
\hline ICD-10 & J16 & Pneumonia due to other infectious organisms, not elsewhere classified \\
\hline ICD-10 & J18 & Pneumonia, organism unspecified \\
\hline ICD-10 & $J 20$ & Acute bronchitis \\
\hline ICD-10 & $J 21$ & Acute bronchiolitis \\
\hline ICD-10 & $J 22$ & Unspecified acute lower respiratory infection \\
\hline ICD-9 & 466 & Acute bronchitis and bronchiolitis \\
\hline ICD-9 & 480 & Viral pneumonia \\
\hline ICD-9 & 481 & Pneumococcal pneumonia \\
\hline ICD-9 & 482 & Other bacterial pneumonia \\
\hline ICD-9 & 483 & Pneumonia due to other specified organism \\
\hline ICD-9 & 484 & Pneumonia in infectious diseases classified elsewhere \\
\hline ICD-9 & 485 & Bronchopneumonia, organism unspecified \\
\hline ICD-9 & 486 & Pneumonia, organism unspecified \\
\hline ICD-9 & 487 & Influenza \\
\hline ICD-9 & 488 & Influenza due to identified avian influenza virus \\
\hline
\end{tabular}

ICD codes used to identify ALRI primary admissions. Note that all more detailed codes below those listed were also included 
account for readmissions, potential missingness of secondary inpatient diagnoses, unavailable outpatient data, and healthcare access and quality for every location. It aggregates inpatient data with claims and outpatient data to produce estimates of individuals who received any care for an ALRI diagnosis. Because this study was primarily focused on inpatient diagnoses of influenza or RSV, these additional corrections were not applied.

\section{Influenza and RSV proportion estimation}

Influenza and RSV admission rates were estimated by modeling the proportion of admissions for ALRI that were attributable to each cause respectively, and then estimating the proportion of total ALRI hospitalizations represented by these diseases, stratified by age, year, and country. The meta-analysis for this model included 156 independent studies on influenza-associated hospitalization rates covering 46 countries with data between 1979 and 2015 for influenza [4-159], and 204 studies on RSV admission rates covering 56 countries with data between 1982 and 2017 [4, 19, 73, 107, 133, 146, 160-356]. Sample size of the study, age range, and location in study cohort, total admissions for ALRI, and admissions for influenza and RSV respectively were extracted from each study. The proportion of ALRI admissions due to influenza and RSV were calculated for each location, age, and year present in the input study data.

A Bayesian regularized trimmed meta-regression (MRBRT) model was generated using ALRI admission metaanalysis data to produce estimates of the proportion of ALRI admissions due to each cause while accounting for within-study heterogeneity by age and location as well as error and bias between sources. Within the MR-BRT framework, the trend over age was modeled as a cubic spline with linear tails on the youngest and oldest age groups and an uninformative Gaussian prior. Linear tails on the age ends were used to smooth behavior of the age pattern at the poles in cases of sparse data, which can be highly unstable in MR-BRT modeling.

Location was used as a covariate at the IHME Global Burden of Disease's super-region and regional levels, to account for potential geographic variation while informing estimations for locations with sparse data by the trend of those with a larger input evidence base. Region was used as a proxy for country-level heterogeneity in order to produce estimates where meta-analysis data was available and admissions data was not or vice versa. IHME's regional categorization by country is available in related literature. Both region and super-region were modeled as a fixed effect with an uninformative Gaussian prior on each. The hierarchical structure of the super-regional and regional models results in child models that follow the same age trend as those of the parents.
The equation for the influenza and RSV MR-BRT models is shown in Eq. 1 below. Detail on the assumptions made by the mixed effects framework, the use of cubic splines on fixed effects, and estimation of the posterior using maximum likelihood estimation are available in related literature [357]. The MR-BRT framework is an $\mathrm{R}$ wrapper for the open source mixed effects LimeTr package, which could be used to replicate the modeling methods described here [358].

$$
\begin{aligned}
\ln \left(p_{(f l u \mid R S V), i, j}\right)= & \operatorname{spline}\left(\operatorname{age}_{i, j} \beta_{1}\right) \\
& +\ln \left(\operatorname{region}_{i, j} \beta_{2}\right) \\
& +\ln \left(\operatorname{super~region~}_{i, j} \beta_{3}\right) \\
& +Z_{i} u_{i, j}+\epsilon_{i j}
\end{aligned}
$$

Where $p_{(f l u \mid R S V), i, j}$ is the proportion of ALRI admissions that are positive for flu or RSV in observation $i$ for study $j$, age a, $_{j}$ is computed using a spline based matrix for age midpoint, region ${ }_{i, j}$ and super region ${ }_{i, j}$ are the fixed effects on GBD region and super region, $Z_{i}$ is a linear map, $u_{i, j}$ are the random effects from meta-analysis study $j$ at observation $i$, and $\epsilon_{i j}$ are measurement errors with a specified covariance.

A hierarchical method was chosen a priori for this analysis as it allowed us to produce estimates for locations with little or no meta-analysis data while still accounting for location-specific randomness in metaanalysis estimates. In the final results of this analysis, location-level estimates maintain age heterogeneity based on the differences of age patterns for ALRI admission rates by each location.

Bootstrapping was performed by taking 1000 samples on the posterior of the MR-BRT model, and uncertainty from the samples was propagated through the remainder of the estimation process as $95 \%$ credible intervals.

\section{Final admission rate estimation}

Admission counts and rates for influenza and RSV were calculated by multiplying the proportions from the influenza and RSV mixed effects attribution models to annual ALRI admission count estimates by age group and location. Seasonality was excluded from the scope of this analysis because seasonal information was not consistently available in influenza and RSV meta-analysis literature. Each location with clinical data received the attribution model fit for the corresponding GBD region, unless no input data for the model existed, in which case an average of the models within the GBD super-region was used. Uncertainty was quantified using the upper and lower uncertainty interval from the fit of the mixed effects model. Due to meta-analysis data sparsity in older ages for the RSV attribution mixed effects model, 
admission rates and counts for RSV were only calculated for children under five.

Influenza and RSV-coded primary admissions were extracted from a subset of clinical administrative datasets as illustrative scenarios in order to compare results of the BIRD analysis to direct ICD extraction with no adjustments. ICD codes used for this comparison can be found in Additional file 2. All locations used to illustrate the comparison contained at least 4-digit ICD detail, which was required to identify primary admissions for RSV.

To assess the limitation of using primary diagnosis alone for ALRI admissions, we extracted non-primary diagnosis detail from the HCUP NIS data which was used to produce US estimates [3]. Diagnosis levels available in HCUP NIS vary by state, but all available diagnosis detail up to the $30^{\text {th }}$ inpatient diagnosis was included for this analysis. We compared primary and nonprimary utilization for the year 2012 from this dataset, and applied influenza-attributable proportion estimates to the complete dataset in order to generate a comparison of influenza rates that include non-primary hospitalizations. We focused specifically on influenza for this sub analysis because of the substantial ALRI utilization as non-primary diagnosis in older ages, as there may be competing complications that would end up coded as primary discharge diagnosis in this population [359362].

\section{Results}

Figures 2 and 3 represent the number of sources of meta-analysis data for the proportion of ALRI admissions attributable to influenza and RSV, respectively. Meta-analysis sources varied in their age ranges and granularity, sample size, and the time range over which studies were conducted. All meta-analysis sources were used to inform the meta-regression analyses as described above.
Metadata about each of IHME's inpatient data sources is available in Additional file 1. Only the inpatient sources that were ICD-9 or ICD-10 coded were used in this analysis. While all sources listed had sufficient ICD detail to extract ALRI utilization rates, not all locations with inpatient admission data have at least 4-digit ICD coding which is required to identify RSV cases by ICD diagnosis alone (see Additional file 2 for the list of 4-digit RSV codes).

Figure 4 shows the proportion of ALRI admissions attributable to influenza and RSV at the super-regional level. Due to limited meta-data availability in older ages for RSV as seen in the figure, admission rates for RSV were only estimated for the under 1 and 1 to 4 year age groups. Data for selected regions are tabulated in Table 2 below.

In these results, influenza represents a significant proportion of ALRI admissions in individuals aged 15 to 55 years, and a lower proportion in the oldest and youngest age groups. Conversely, RSV represents over $30 \%$ of all ALRI admissions for infants under 1 year and over $18 \%$ for infants aged 1-4, but the proportion of ALRI admissions attributable to RSV drops dramatically in age groups beyond the age of 5 years.

Comparisons of admission rates calculated through the BIRD analysis versus those coded directly with influenza and RSV ICD codes for locations with sufficient ICD granularity are shown in Figs. 5 and 6, and tabulated in Tables 3 and 4. For almost all age groups, the methods as described in this paper estimated a higher national admission rate than the rate of directly coded influenza or RSV admissions in the same inpatient sources. Many inpatient data sources used at IHME are coded only to three or four digits, in which case it is less accurate or even not possible to estimate RSV admission rates. Detail on inpatient clinical sources and ICD granularity is listed in Additional file 1, and the ICD codes used to determine influenza and RSV inpatient admissions are listed in Additional file 2. The full dataset

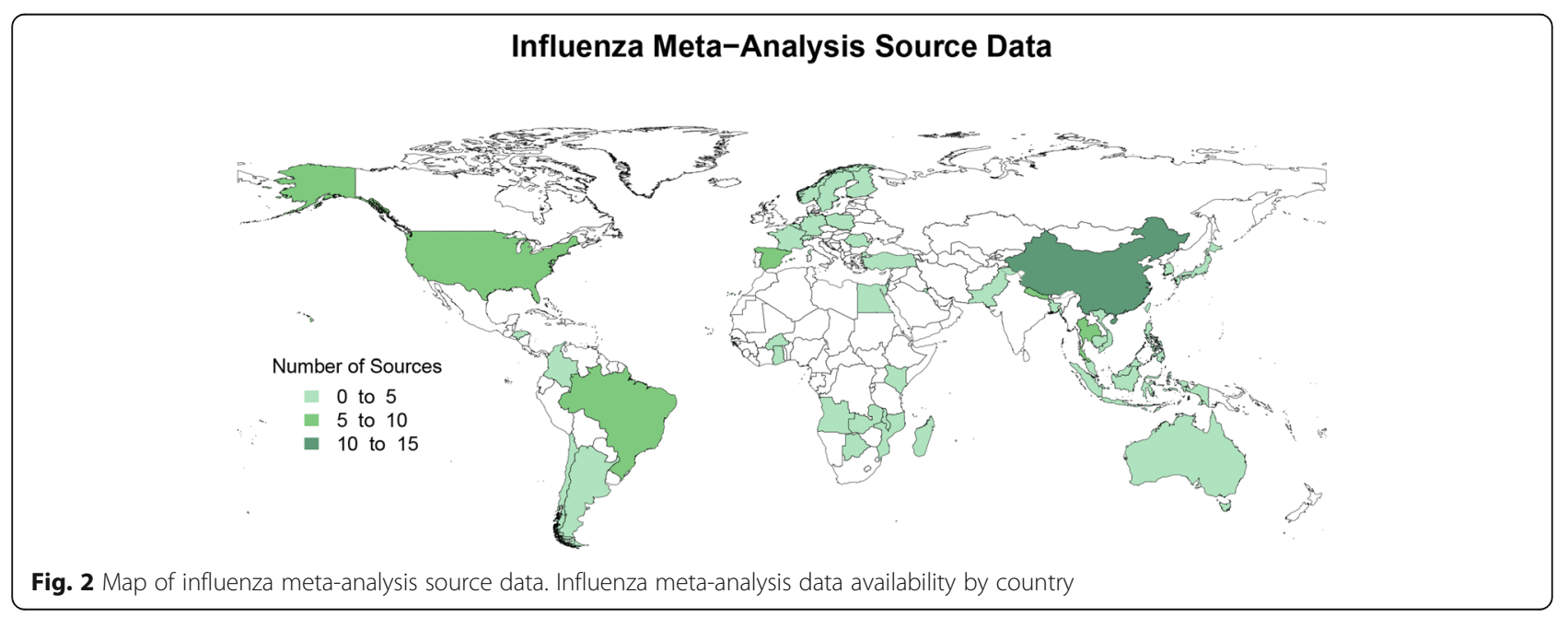




\section{RSV Meta-Analysis Source Data}

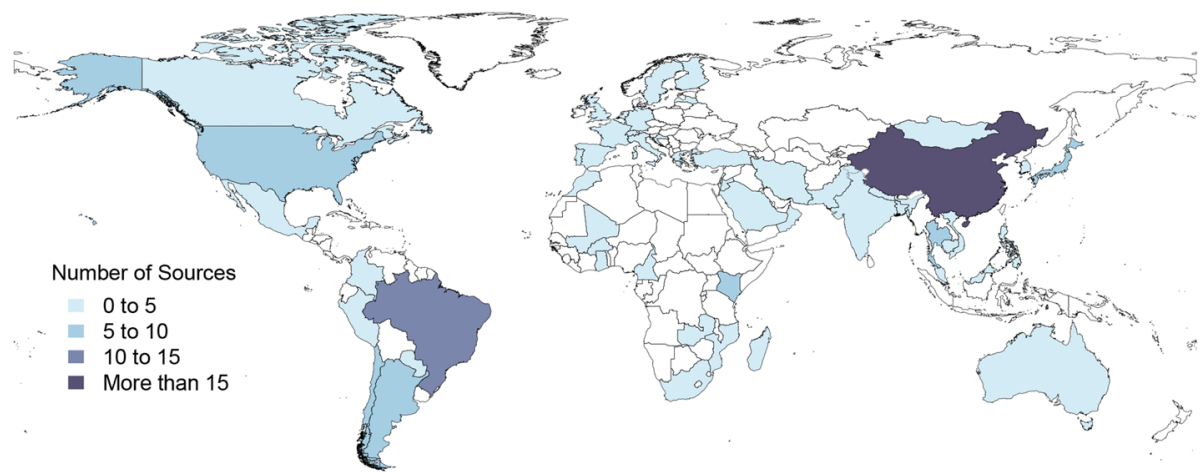

Fig. 3 Map of RSV meta-analysis source data. RSV meta-analysis data availability by country

of BIRD estimates of influenza and RSV admissions by age, year, and country are available in Additional file 3.

As non-primary diagnoses were not available for the majority of sources of inpatient admission data, only primary diagnosis was used to expand the number of useable sources and retain consistency across locations. We conducted a sensitivity analysis comparing the average primary and non-primary admission rates for ALRI in the USA from 2002 to 2012 to illustrate the potential impact of limiting the analysis to ALRI as primary diagnosis only.

Influenza admission rates in the USA by primaryonly diagnosis and primary and non-primary diagnosis are shown in Fig. 7. The impact of non-primary diagnoses was a 1.4-fold increase in rates estimates for children $<1$ year, and nearly a 2.5 -fold increase in rates estimated in the $18-49,50$ to 64 , and 65 plus age groups.

\section{Discussion}

While influenza and RSV-associated healthcare utilization is acknowledged as a global problem, gaps in quantifying the magnitude of this problem exist due to lack in representative data availability across locations that makes assessing admission rates within or across countries challenging. Traditional methods of burden
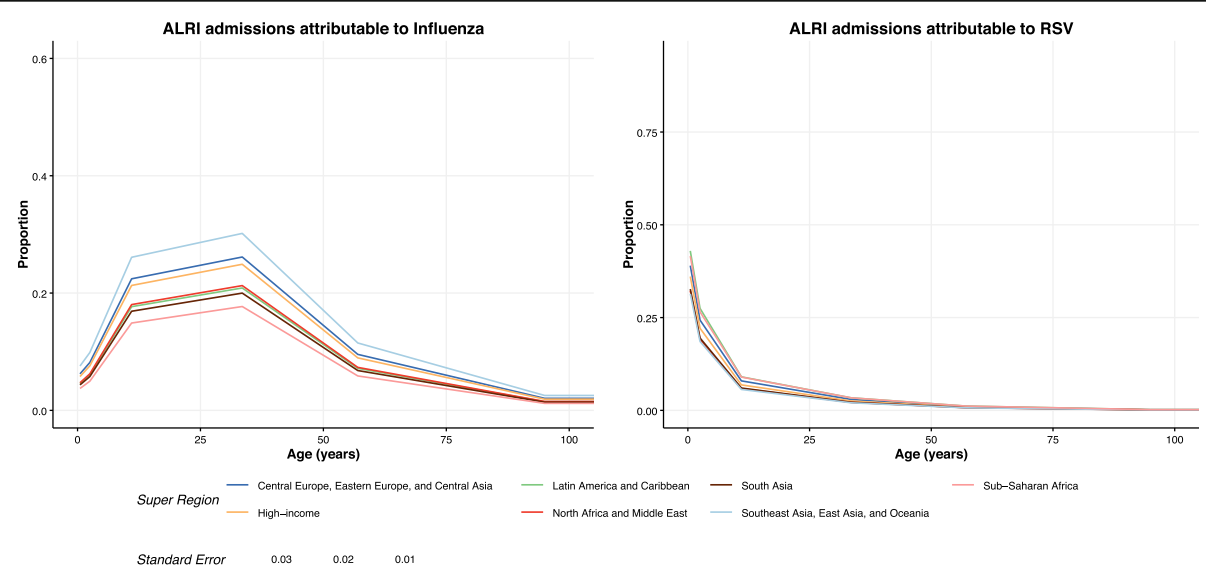

Fig. 4 Proportion of ALRI admissions attributable to influenza and RSV. Influenza and RSV proportion models and meta-analysis input data for all IHME super-regions. Data point and model line colors reflect the GBD super region. Size of data points is scaled by the standard error of each datum 
Table 2 Proportion influenza and RSV positive by GBD super-region

\begin{tabular}{|c|c|c|c|}
\hline GBD super region & Age & $\begin{array}{l}\text { Influenza positive proportion of ALRI } \\
\text { admissions ( } 95 \% \text { UI) }\end{array}$ & $\begin{array}{l}\text { RSV positive proportion of ALRI } \\
\text { admissions ( } 95 \% \text { UI) }\end{array}$ \\
\hline $\begin{array}{l}\text { Central Europe, Eastern Europe, and } \\
\text { Central Asia }\end{array}$ & $\begin{array}{l}<1 \\
\text { year }\end{array}$ & $0.06(0.01-0.25)$ & $0.39(0.14-0.72)$ \\
\hline $\begin{array}{l}\text { Central Europe, Eastern Europe, and } \\
\text { Central Asia }\end{array}$ & 1 to 4 & $0.08(0.01-0.31)$ & $0.24(0.07-0.55)$ \\
\hline $\begin{array}{l}\text { Central Europe, Eastern Europe, and } \\
\text { Central Asia }\end{array}$ & $\begin{array}{l}5 \text { to } \\
17\end{array}$ & $0.22(0.03-0.63)$ & $0.08(0.02-0.23)$ \\
\hline $\begin{array}{l}\text { Central Europe, Eastern Europe, and } \\
\text { Central Asia }\end{array}$ & $\begin{array}{l}18 \text { to } \\
49\end{array}$ & $0.26(0.04-0.68)$ & $0.03(0.01-0.1)$ \\
\hline $\begin{array}{l}\text { Central Europe, Eastern Europe, and } \\
\text { Central Asia }\end{array}$ & $\begin{array}{l}50 \text { to } \\
64\end{array}$ & $0.1(0.01-0.35)$ & $0.01(0-0.03)$ \\
\hline $\begin{array}{l}\text { Central Europe, Eastern Europe, and } \\
\text { Central Asia }\end{array}$ & $\begin{array}{l}65 \\
\text { plus }\end{array}$ & $0.02(0-0.09)$ & $0(0-0.01)$ \\
\hline High-income & $\begin{array}{l}<1 \\
\text { year }\end{array}$ & $0.06(0.01-0.23)$ & $0.36(0.12-0.68)$ \\
\hline High-income & 1 to 4 & $0.08(0.01-0.29)$ & $0.22(0.06-0.51)$ \\
\hline High-income & $\begin{array}{l}5 \text { to } \\
17\end{array}$ & $0.21(0.03-0.62)$ & $0.07(0.02-0.2)$ \\
\hline High-income & $\begin{array}{l}18 \text { to } \\
49\end{array}$ & $0.25(0.04-0.67)$ & $0.03(0.01-0.08)$ \\
\hline High-income & $\begin{array}{l}50 \text { to } \\
64\end{array}$ & $0.09(0.01-0.34)$ & $0.01(0-0.03)$ \\
\hline High-income & $\begin{array}{l}65 \\
\text { plus }\end{array}$ & $0.02(0-0.08)$ & $0(0-0.01)$ \\
\hline Latin America and Caribbean & $\begin{array}{l}<1 \\
\text { year }\end{array}$ & $0.05(0-0.19)$ & $0.43(0.16-0.76)$ \\
\hline Latin America and Caribbean & 1 to 4 & $0.06(0.01-0.24)$ & $0.27(0.08-0.6)$ \\
\hline Latin America and Caribbean & $\begin{array}{l}5 \text { to } \\
17\end{array}$ & $0.18(0.02-0.56)$ & $0.09(0.02-0.26)$ \\
\hline Latin America and Caribbean & $\begin{array}{l}18 \text { to } \\
49\end{array}$ & $0.21(0.03-0.62)$ & $0.03(0.01-0.11)$ \\
\hline Latin America and Caribbean & $\begin{array}{l}50 \text { to } \\
64\end{array}$ & $0.07(0.01-0.29)$ & $0.01(0-0.04)$ \\
\hline Latin America and Caribbean & $\begin{array}{l}65 \\
\text { plus }\end{array}$ & $0.01(0-0.07)$ & $0(0-0.01)$ \\
\hline North Africa and Middle East & $\begin{array}{l}<1 \\
\text { year }\end{array}$ & $0.05(0-0.19)$ & $0.32(0.1-0.66)$ \\
\hline North Africa and Middle East & 1 to 4 & $0.06(0.01-0.25)$ & $0.19(0.05-0.48)$ \\
\hline North Africa and Middle East & $\begin{array}{l}5 \text { to } \\
17\end{array}$ & $0.18(0.02-0.56)$ & $0.06(0.01-0.18)$ \\
\hline North Africa and Middle East & $\begin{array}{l}18 \text { to } \\
49\end{array}$ & $0.21(0.03-0.61)$ & $0.02(0-0.07)$ \\
\hline North Africa and Middle East & $\begin{array}{l}50 \text { to } \\
64\end{array}$ & $0.07(0.01-0.29)$ & $0.01(0-0.03)$ \\
\hline North Africa and Middle East & $\begin{array}{l}65 \\
\text { plus }\end{array}$ & $0.02(0-0.07)$ & $0(0-0)$ \\
\hline South Asia & $\begin{array}{l}<1 \\
\text { year }\end{array}$ & $0.04(0-0.18)$ & $0.33(0.1-0.67)$ \\
\hline South Asia & 1 to 4 & $0.06(0.01-0.23)$ & $0.19(0.05-0.49)$ \\
\hline South Asia & $\begin{array}{l}5 \text { to } \\
17\end{array}$ & $0.17(0.02-0.54)$ & $0.06(0.01-0.18)$ \\
\hline South Asia & $\begin{array}{l}18 \text { to } \\
49\end{array}$ & $0.2(0.03-0.59)$ & $0.02(0-0.07)$ \\
\hline
\end{tabular}


Table 2 Proportion influenza and RSV positive by GBD super-region (Continued)

\begin{tabular}{|c|c|c|c|}
\hline GBD super region & Age & $\begin{array}{l}\text { Influenza positive proportion of ALRI } \\
\text { admissions ( } 95 \% \text { UI) }\end{array}$ & $\begin{array}{l}\text { RSV positive proportion of ALRI } \\
\text { admissions ( } 95 \% \text { UI) }\end{array}$ \\
\hline South Asia & $\begin{array}{l}50 \text { to } \\
64\end{array}$ & $0.07(0.01-0.27)$ & $0.01(0-0.03)$ \\
\hline South Asia & $\begin{array}{l}65 \\
\text { plus }\end{array}$ & $0.01(0-0.06)$ & $0(0-0)$ \\
\hline Southeast Asia, East Asia, and Oceania & $\begin{array}{l}<1 \\
\text { year }\end{array}$ & $0.08(0.01-0.29)$ & $0.31(0.1-0.64)$ \\
\hline Southeast Asia, East Asia, and Oceania & 1 to 4 & $0.1(0.01-0.36)$ & $0.19(0.05-0.46)$ \\
\hline Southeast Asia, East Asia, and Oceania & $\begin{array}{l}5 \text { to } \\
17\end{array}$ & $0.26(0.04-0.68)$ & $0.06(0.01-0.17)$ \\
\hline Southeast Asia, East Asia, and Oceania & $\begin{array}{l}18 \text { to } \\
49\end{array}$ & $0.3(0.05-0.73)$ & $0.02(0-0.07)$ \\
\hline Southeast Asia, East Asia, and Oceania & $\begin{array}{l}50 \text { to } \\
64\end{array}$ & $0.11(0.01-0.41)$ & $0.01(0-0.02)$ \\
\hline Southeast Asia, East Asia, and Oceania & $\begin{array}{l}65 \\
\text { plus }\end{array}$ & $0.03(0-0.11)$ & $0(0-0)$ \\
\hline Sub-Saharan Africa & $\begin{array}{l}<1 \\
\text { year }\end{array}$ & $0.04(0-0.16)$ & $0.42(0.15-0.75)$ \\
\hline Sub-Saharan Africa & 1 to 4 & $0.05(0-0.21)$ & $0.27(0.08-0.59)$ \\
\hline Sub-Saharan Africa & $\begin{array}{l}5 \text { to } \\
17\end{array}$ & $0.15(0.02-0.49)$ & $0.09(0.02-0.26)$ \\
\hline Sub-Saharan Africa & $\begin{array}{l}18 \text { to } \\
49\end{array}$ & $0.18(0.02-0.55)$ & $0.03(0.01-0.11)$ \\
\hline Sub-Saharan Africa & $\begin{array}{l}50 \text { to } \\
64\end{array}$ & $0.06(0.01-0.24)$ & $0.01(0-0.04)$ \\
\hline Sub-Saharan Africa & $\begin{array}{l}65 \\
\text { plus }\end{array}$ & $0.01(0-0.06)$ & $0(0-0.01)$ \\
\hline
\end{tabular}

Proportion of ALRI admissions that are influenza and RSV positive for all IHME super-regions stratified by BIRD age group

estimation based on laboratory-confirmed cases are not possible in most settings because testing patients with ALRI is not routine care. This analysis utilizes clinical administrative data which is widely available across countries, and presents a means of utilization estimation that can be more robust than direct ICD extraction alone. The approach, however, has important limitations for influenza when considering older adults.

Although the true burden of RSV in children is unknown, estimates of RSV admission rates from this study are generally consistent with published literature on RSV hospital utilization in children under 5 . Shi et al estimate hospital admission rates of $26.3(22.8-30.2)$ per 1000 in
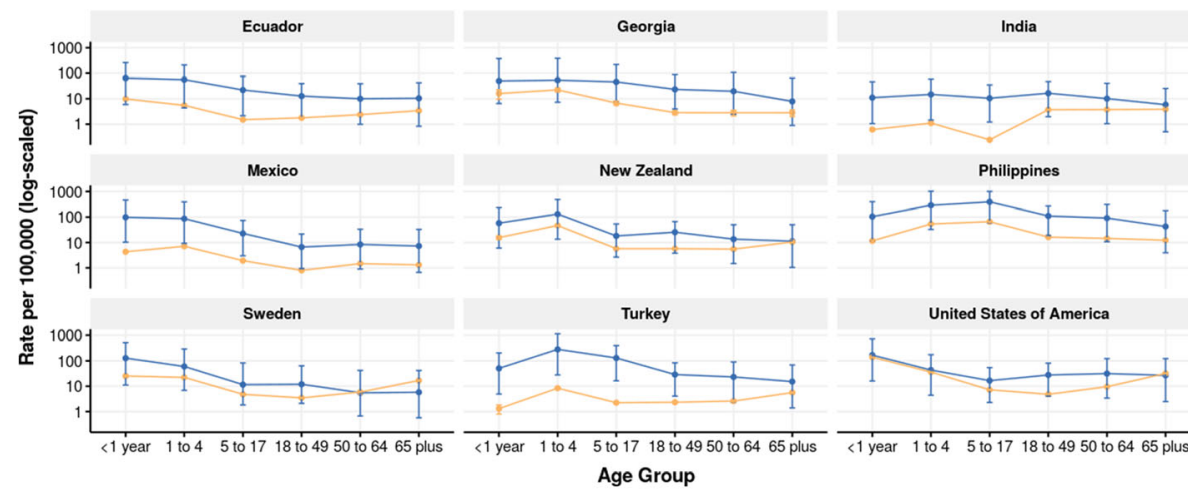

$\rightarrow$ BIRD rate $\rightarrow$ ICD-Coded

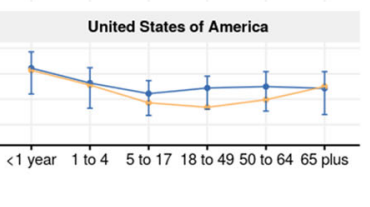

Fig. 5 Influenza admission rate by BIRD analysis and ICD coding. Influenza admission rate per 100,000 people by age as produced by BIRD analysis (blue) and simple raw ICD code extraction (yellow). 95\% Cl shown for both estimates 


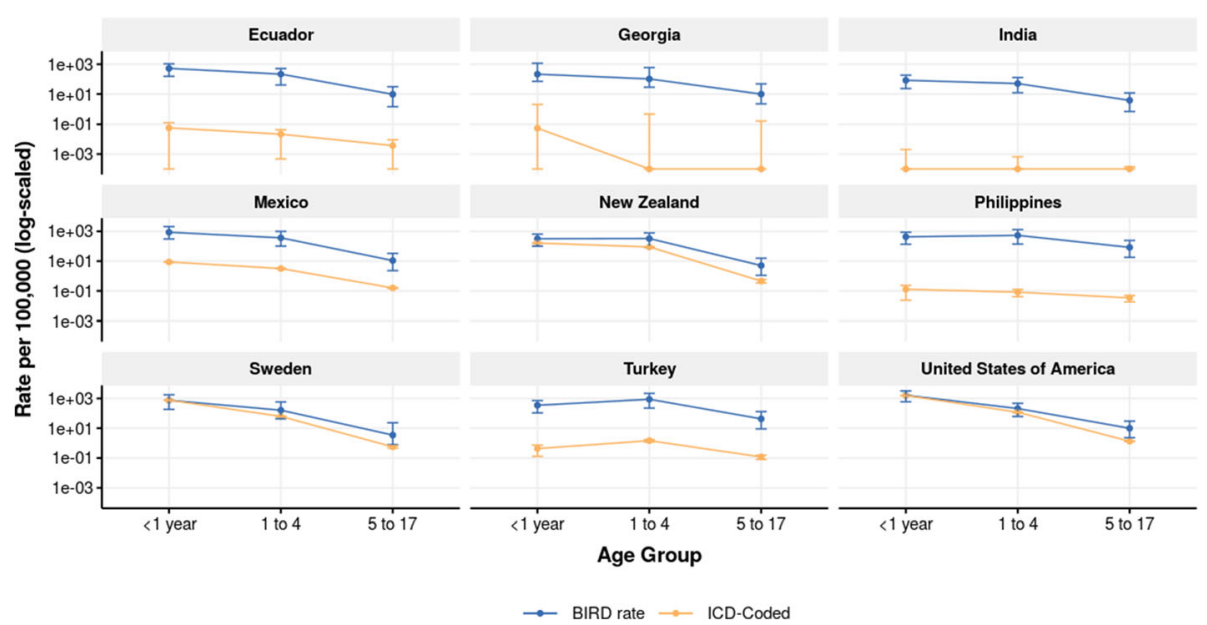

Fig. 6 RSV admission rate by BIRD analysis and ICD coding. RSV admission rate per 100,000 by age as produced by BIRD analysis (blue) and simple raw ICD code extraction (yellow). 95\% Cl shown for both estimates

children aged 1-5 months, $11.3(6.1-20.9)$ per 1000 in children 6-11 months, and $1.4(0.9-2.0)$ per 1000 in children 12-59 months old in World Bank High Income countries [363]. Reeves et al. found admission rates for RSV of $35.1(32.9-38.9)$ per 1000 in children under 1 year and 5.31 (4.46-6.59) per 1000 in children age 1-4 years old in England [364]. Estimates from the BIRD analysis as shown in Table 4 are lower in high-income settings for children under 1 year of age than either study, but fall between estimates of older children as described in the literature. Further discussion and comparisons of the results of the BIRD analysis for RSV to other RSV estimation methods are available in related literature [365].

Our estimated admission rates for influenza are generally an underestimate of rates previously published, particularly in the $65+$ age group [366, 367]. For the USA and Sweden at age $65+$, the simple extracted ICD-coded admission rate from administrative datasets surpasses the rate produced by this study. The inclusion of nonprimary diagnoses did increase estimates for influenza in the USA by more than $50 \%$. Nonetheless, these rates are still lower than those produced by comparable studies in the oldest age group. Previous studies estimate that anywhere between 39.5 and $96.6 \%$ of all admissions across all ages for influenza have a primary diagnosis related to influenza, and the relative proportion of burden as a primary diagnosis in this analysis fall within that range [359-362]. While using only the primary diagnosis allowed us to maintain consistency with the 33 sources containing only primary diagnostic detail, future iterations of this method should consider inclusion of non-primary diagnoses for more comprehensive utilization estimation, if at the expense of geographic coverage.
Estimates of the proportion of influenza-positive adults age $65+$ were also generally lower than existing literature. Jain et al. estimate that $4 \%$ adults aged $65-79$ years and $5 \%$ adults 80 or older hospitalized for pneumonia in select US cities test positive for influenza [32]. Monto et al. report that $10.9 \%$ of adults aged 50 or older presenting with acute respiratory illness are influenza positive, in a study of families in Ann Arbor Michigan over 3 years [69]. Our analysis estimates $1.9 \%(0.02-8.4)$ of ALRI admissions in ages 65+ in IHME high-income settings are influenza positive cases. While the upper bound of this estimate more closely aligns with existing published literature, the proportion positive estimated from the BIRD project is low because of data sparsity in oldest ages. The age spline method used in the MR-BRT analysis depends on age midpoint of meta-analysis input data instead of accounting for an age range, which narrows the number of estimates representing older ages. Inclusion of additional meta-analysis data and incorporation of more sophisticated age range splitting could produce more robust proportion estimates in older ages.

The methodology employed by this analysis is comparable to previous burden estimates for influenza produced by IHME in the application of a proportion model to estimates of total lower respiratory infection [368]. However, estimates from the BIRD project were formed using a categorical approach that did not account for the relative risk of ALRI in cases of confirmed influenza or RSV. Instead, the proportion of ALRI hospitalizations was assumed to be a proxy of total utilization. Additionally, the BIRD analysis focuses exclusively on inpatient hospital utilization instead of incidence or mortality, which reduced the assumptions made about how trends in utilization can be extended to other metrics. Finally, the hierarchical method of modeling proportion positive 
Table 3 Influenza rates by BIRD analysis and ICD code extraction for select locations

\begin{tabular}{|c|c|c|c|}
\hline Country & Age group & BIRD rate per 100,000 (95\% UI) & ICD-coded rate per $100,000(95 \%$ UI) \\
\hline Ecuador & $<1$ year & $64.5(6-260.9)$ & $9.8(9.1-10.6)$ \\
\hline Ecuador & 1 to 4 & $56.5(4.3-210)$ & $5.5(5.2-5.8)$ \\
\hline Ecuador & 5 to 17 & $22.1(2.2-75.5)$ & $1.5(1.4-1.6)$ \\
\hline Ecuador & 18 to 49 & $12.8(1.7-39.6)$ & $1.8(1.7-1.8)$ \\
\hline Ecuador & 50 to 64 & $10(1-39.1)$ & $2.4(2.2-2.6)$ \\
\hline Ecuador & 65 plus & $10.5(0.8-42.7)$ & $3.4(3.1-3.7)$ \\
\hline Georgia & $<1$ year & $50.3(6.5-375.9)$ & $16.2(9.7-22.7)$ \\
\hline Georgia & 1 to 4 & $54(7.3-385.5)$ & $22.5(18.8-26.1)$ \\
\hline Georgia & 5 to 17 & $46.2(8-219.6)$ & $6.8(5.6-8)$ \\
\hline Georgia & 18 to 49 & $23.5(4-87.6)$ & $2.8(2.4-3.3)$ \\
\hline Georgia & 50 to 64 & $19.8(2.4-107.2)$ & $2.8(2.1-3.5)$ \\
\hline Georgia & 65 plus & $7.9(0.9-64.8)$ & $2.8(2-3.6)$ \\
\hline India & $<1$ year & $11.1(1-46.4)$ & $0.6(0.6-0.7)$ \\
\hline India & 1 to 4 & $14.9(1.5-59.8)$ & $1.1(1.1-1.1)$ \\
\hline India & 5 to 17 & $10.5(1.2-35.1)$ & $0.2(0.2-0.2)$ \\
\hline India & 18 to 49 & $16.6(2-47.7)$ & $3.7(3.7-3.7)$ \\
\hline India & 50 to 64 & $10.2(1-40.8)$ & $3.8(3.7-3.8)$ \\
\hline India & 65 plus & $5.9(0.5-25.4)$ & $3.9(3.8-3.9)$ \\
\hline Mexico & $<1$ year & $98.4(10.3-458.1)$ & $4.3(4.1-4.5)$ \\
\hline Mexico & 1 to 4 & $87(9.3-388.3)$ & $7.1(7-7.2)$ \\
\hline Mexico & 5 to 17 & $22.8(3-74)$ & $1.9(1.9-2)$ \\
\hline Mexico & 18 to 49 & $6.6(0.9-21.6)$ & $0.8(0.8-0.8)$ \\
\hline Mexico & 50 to 64 & $8.4(0.9-33.2)$ & $1.5(1.4-1.5)$ \\
\hline Mexico & 65 plus & $7.3(0.7-32.7)$ & $1.3(1.2-1.4)$ \\
\hline New Zealand & $<1$ year & $58(6-231.5)$ & $15.7(13.3-18.1)$ \\
\hline New Zealand & 1 to 4 & $131.6(13.6-482.9)$ & $46.7(44.6-48.8)$ \\
\hline New Zealand & 5 to 17 & $18.1(2.7-54)$ & $5.7(5.3-6.1)$ \\
\hline New Zealand & 18 to 49 & $25.4(3.8-66.7)$ & $5.7(5.5-6)$ \\
\hline New Zealand & 50 to 64 & $13.6(1.5-50.1)$ & $5.5(5.1-5.9)$ \\
\hline New Zealand & 65 plus & $11.3(1-50.2)$ & $10.5(9.8-11.2)$ \\
\hline Philippines & $<1$ year & $104.4(11.4-394.8)$ & $11.6(10.7-12.5)$ \\
\hline Philippines & 1 to 4 & $288.2(32.6-1024)$ & $53.7(52.6-54.7)$ \\
\hline Philippines & 5 to 17 & 390.7 (60.8-1007.2) & $66.2(65.5-66.8)$ \\
\hline Philippines & 18 to 49 & $110.6(18.8-267.5)$ & $16.3(16-16.6)$ \\
\hline Philippines & 50 to 64 & $91.4(10.7-310.1)$ & $14.5(14-15)$ \\
\hline Philippines & 65 plus & $42.5(3.9-179.1)$ & $12.3(11.6-13.1)$ \\
\hline Sweden & $<1$ year & $128.5(11.1-523.3)$ & $25.2(22.8-27.7)$ \\
\hline Sweden & 1 to 4 & $60.1(6.9-294.4)$ & $22.3(21.2-23.5)$ \\
\hline Sweden & 5 to 17 & $11.6(1.8-82.7)$ & $4.8(4.5-5.1)$ \\
\hline Sweden & 18 to 49 & $12(2.1-63.8)$ & $3.5(3.3-3.6)$ \\
\hline Sweden & 50 to 64 & $5.5(0.7-41.9)$ & $5.9(5.6-6.2)$ \\
\hline Sweden & 65 plus & $5.8(0.6-41.7)$ & $16.9(16.2-17.5)$ \\
\hline Turkey & $<1$ year & $50.8(4.9-205.6)$ & $1.3(0.8-1.8)$ \\
\hline Turkey & 1 to 4 & $284.7(28-1137)$ & $8.4(7.8-9)$ \\
\hline
\end{tabular}


Table 3 Influenza rates by BIRD analysis and ICD code extraction for select locations (Continued)

\begin{tabular}{llll}
\hline Country & Age group & BIRD rate per $\mathbf{1 0 0 , 0 0 0}(\mathbf{9 5} \%$ UI) & ICD-coded rate per $\mathbf{1 0 0 , 0 0 0}(\mathbf{9 5} \% \mathbf{U I})$ \\
\hline Turkey & 5 to 17 & $130.3(16.5-400.1)$ & $2.2(2.1-2.4)$ \\
Turkey & 18 to 49 & $28.9(4.1-83.5)$ & $2.3(2.2-2.4)$ \\
Turkey & 50 to 64 & $23.2(2.4-90.7)$ & $2.6(2.4-2.8)$ \\
Turkey & 65 plus & $15.3(1.4-68.9)$ & $5.6(5.2-6.1)$ \\
United States of America & $<1$ year & $168.4(16.2-714.1)$ & $139.5(138.4-140.7)$ \\
United States of America & 1 to 4 & $43.4(4.4-175.8)$ & $36.1(35.8-36.4)$ \\
United States of America & 5 to 17 & $16.6(2.3-54.5)$ & $7.2(7.1-7.3)$ \\
United States of America & 18 to 49 & $27.8(4.1-80.9)$ & $4.8(4.8-4.8)$ \\
United States of America & 50 to 64 & $31.6(3.4-122.6)$ & $9.6(9.5-9.6)$ \\
United States of America & 65 plus & $27(2.5-122.6)$ & $32(31.8-32.2)$ \\
\hline
\end{tabular}

BIRD estimates of rates of influenza admission as compared to the rate from a raw ICD code extraction. BIRD and raw coded rate are produced across all years of available data for each country

by region and super-region was a novel approach used in burden analysis to allow for estimates in locations with sparser meta-analysis data to have more robust proportion estimates over age. IHME's GBD global influenza admission rate estimates were higher than most of those predicted for countries included in BIRD analysis, at 123.8 per 100,000 (CI: 48.5-300.2) across all ages as compared to BIRD all-age rates of 29.7 per 100,000 (CI: 3.64-101.7) in the USA to $195.81(183.88-207.74)$ in the Philippines.

This study met limitations that are consistent with any analysis developed from clinical administrative data.
Availability of inpatient admissions data in some lowerto middle-income countries and meta-analysis data for RSV in older children and adults limited the scope of this analysis, and additional sources of both types of data would improve accuracy of estimates. Availability of inpatient data and proportion meta-analysis at a seasonal or monthly granularity would allow for more relevant analysis during peak influenza and RSV seasons. Additionally, we encountered technical limitations in handling of meta-analysis with point estimates for proportion positive spanning large age ranges, and in the assumption made that influenza and RSV proportions across

Table 4 RSV rates by BIRD analysis and ICD code extraction for select locations

\begin{tabular}{|c|c|c|c|}
\hline Country & Age group & BIRD Rate per 100,000 (95\% UI) & ICD-coded rate per 100,000 (95\% UI) \\
\hline Ecuador & $<1$ year & $525.9(154.2-1069.9)$ & $0.1(0-0.1)$ \\
\hline Ecuador & 1 to 4 & $216.4(40.5-508.3)$ & $0(0-0)$ \\
\hline Georgia & $<1$ year & $214.2(71.2-1163.1)$ & $0.1(0-2)$ \\
\hline Georgia & 1 to 4 & $102.9(28.6-595.6)$ & $0(0-0.5)$ \\
\hline India & $<1$ year & $83.4(23.3-184.1)$ & $0(0-0)$ \\
\hline India & 1 to 4 & $50.3(12.1-127.4)$ & $0(0-0)$ \\
\hline Mexico & $<1$ year & $865.6(306.8-2077.7)$ & $8.8(8.4-9.1)$ \\
\hline Mexico & 1 to 4 & $364.3(101.4-992.8)$ & $3.2(3.1-3.3)$ \\
\hline New Zealand & $<1$ year & $318.3(100.4-646.3)$ & $163.3(155.6-171)$ \\
\hline New Zealand & 1 to 4 & $327.7(82.2-781.2)$ & $89.4(86.5-92.2)$ \\
\hline Philippines & $<1$ year & $429.4(135.6-876.1)$ & $0.1(0-0.2)$ \\
\hline Philippines & 1 to 4 & $536.1(138.8-1306.9)$ & $0.1(0-0.1)$ \\
\hline Sweden & $<1$ year & 750.8 (184-1744.6) & 758.7 (746.1-771.3) \\
\hline Sweden & 1 to 4 & $160.8(43.1-581.1)$ & $62(60.2-63.9)$ \\
\hline Turkey & $<1$ year & $347.8(107-711.8)$ & $0.4(0.1-0.7)$ \\
\hline Turkey & 1 to 4 & $875(224.2-2177)$ & $1.5(1.2-1.7)$ \\
\hline United States of America & $<1$ year & $1623.6(595.2-3201.2)$ & 1557 (1553.2-1560.8) \\
\hline United States of America & 1 to 4 & $209.2(61.6-469.9)$ & $118.4(117.9-118.9)$ \\
\hline
\end{tabular}

BIRD estimates of rates of RSV admission as compared to the rate from a raw ICD code extraction. BIRD and raw coded rate are produced across all years of available data for each country 


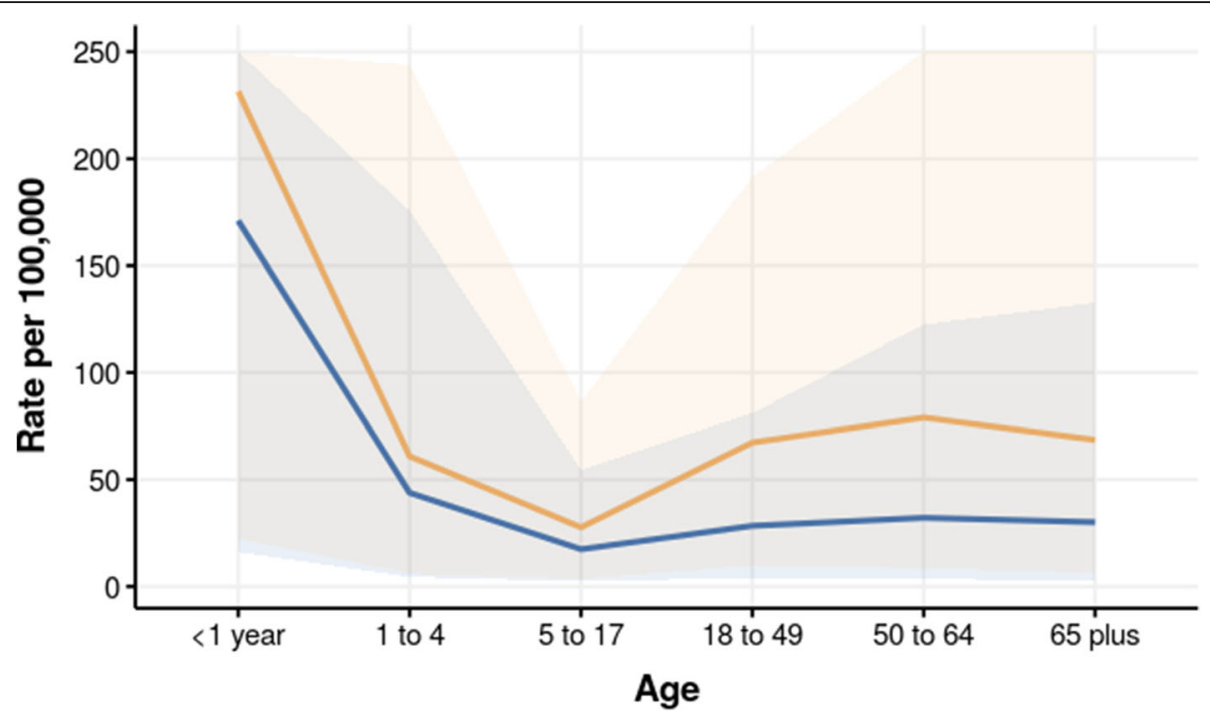

Primary - Primary and nonprimary

Fig. 7 Primary versus nonprimary influenza admission rate in the USA, 2012. Influenza admission rate by diagnosis position, in US HCUP NIS data. Uncertainty is capped in order to show estimated age pattern

countries will follow the same pattern over age. Finally, the rates estimated in this analysis represent utilization rates of influenza and RSV present in individuals who have a primary admission diagnosis of acute lower respiratory infection. Accounting for non-inpatient care including urgent or emergency departments and adjustments for non-primary diagnosis when ALRI is not the primary reason for visit would further improve the estimates produced by this analysis.

In addition to addressing the limitations described, future iterations of this methodology could be expanded to estimates of incidence or prevalence from utilization by accounting for health care access and care-seeking behavior. Furthermore, deeper investigation of goodness-of-fit of the proportion models through out of sample estimation would provide additional validation for the methods proposed here and potentially identify additional areas for refinement of the proportion models.

\section{Conclusions}

Because of heterogeneity in coding practices between countries and limited availability of data at sufficient granularity for precise burden estimation, there are few reliable sources of influenza and RSV hospital utilization or incidence that are provided on a global scale. The application of meta-analysis for proportion positive to overall ALRI utilization is a non-traditional means of estimation that indicate promise in other applications where direct measurement of ICD diagnoses cannot provide accurate estimates of rates of disease and where surveillance data are not available. However, the method shows much uncertainty when considering influenza in older adults that could be a function of considerable heterogeneity in ALRI coding between countries (i.e., as primary vs secondary cause), and in the age profile of proportion positivity for influenza and RSV across studies. While this method is interesting because it is based on clinical administrative data that is available from many countries globally, additional refinement of admission processing methodology and inclusion of more data over ages would enable greater comparability to existing influenza and RSV utilization literature.

\section{Abbreviations}

ALRI: Acute lower respiratory infections; RSV: Respiratory syncytial virus; ICD: International Classification of Disease; BIRD: Burden of Influenza and RSV Disease; IHME: Institute for Health Metrics and Evaluation; GBD: Global Burden of Disease; MR-BRT: Bayesian regularized trimmed meta-regression; HCUP NIS: Healthcare Cost and Utilization Project National Inpatient Sample

\section{Supplementary Information}

The online version contains supplementary material available at https://doi. org/10.1186/s12963-021-00252-5.

Additional file 1. IHME Inpatient Data Metadata. Description of data: Detailed information including number of years of data, length of ICD codes, and total number of inpatient admissions for each source of clinical administrative data used in this study. All data is in the custody of the Institute of Health Metrics and Evaluation, and is available in the Global Health Data Exchange (ghdx.healthdata.org).

Additional file 2. Influenza and RSV ICD Codes. Description of data: The ICD-9 and ICD-10 codes used to identify influenza and RSV admissions 
from raw ICD extraction, to compare against the utilization rates produced by the BIRD study.

Additional file 3. Influenza and RSV Inpatient Admission Rates for All Country-Years of Clinical Administrative Data. Description of data: Tabulated inpatient admission rates with uncertainty for all ages and years available for each country included in the BIRD analysis. Countries where clinical administrative data from IHME was available are all included in this dataset.

\section{Acknowledgements}

Thanks to Wil Van Cleve, Greg Roth and Zachary Jones who contributed to the production of this manuscript.

\section{Authors' contributions}

EJ contributed to data extraction, led data analysis and interpretation, and drafted the manuscript. DS contributed to data extraction and analysis and provided critical review of the manuscript. SC designed the study, contributed to data interpretation, and provided critical review of the manuscript. CC designed the study, contributed to data interpretation, and provided critical review of the manuscript. YL contributed to data extraction, analysis, and interpretation and provided critical review of the manuscript. CM designed the study, contributed to data interpretation, and provided critical review of the manuscript. HN designed the study, contributed to data interpretation, and provided critical review of the manuscript. JP designed the study, contributed to data analysis, and interpretation and provided critical review of the manuscript. TP contributed to data analysis and interpretation and provided critical review of the manuscript. TS contributed to data extraction and provided critical review of the manuscript. CV designed the study, contributed to data interpretation and provided critical review of the manuscript. SJ designed the study, contributed to data interpretation, and provided critical review of the manuscript. All authors have read, provided comments, and approved this manuscript.

\section{Funding}

The BIRD project was supported by a grant from the Foundation for Influenza Epidemiology (www.ghisn.org). The funding source for this project was not involved in study design, data extraction and analysis, interpretation of results or drafting of the manuscript. Sandra S Chaves and Cedric Mahe contributed to the, interpretation of results and writing up of the manuscript and report as members of the Foundation.

\section{Availability of data and materials}

Inpatient admissions datasets and influenza meta-analysis data as used in this analysis are available via IHME's Global Health Data Exchange (GHDx), http:// ghdx.healthdata.org/ [2, 3, 369-390].

RSV meta-analysis data is available through the Edinburgh Datashare, https:// datashare.is.ed.ac.uk/handle/10283/3611 [365].

\section{Declarations}

\section{Ethics approval and consent to participate}

Not applicable.

\section{Consent for publication}

Not applicable.

\section{Competing interests}

Sandra S Chaves and Cedric Mahe are employees of Sanofi Pasteur, but the content of this paper is not representative of the views of their organization. Spencer $L$ James is an employee of Genentech, a subsidiary of Roche, but was an employee of IHME during his involvement in the grant. Cecile Viboud is an employee of the $\mathrm{NIH}$, but this study does not necessarily represent the views of the $\mathrm{NIH}$ or the US government. All other authors declare no competing interests.

\section{Author details}

${ }^{1}$ Institute of Health Metrics and Evaluation, University of Washington, Seattle, USA. ${ }^{2}$ Foundation for Influenza Epidemiology, Fondation de France, Paris, France. ${ }^{3}$ Vaccine Epidemiology and Modeling Department, Sanofi Pasteur, Lyon, France. ${ }^{4}$ Centre for Global Health, Usher Institute, University of
Edinburgh, Edinburgh, UK. ${ }^{5}$ Netherlands Institute for Health Services Research (Nivel), Utrecht, Netherlands. ${ }^{6}$ Fogarty International Center, National Institutes of Health, Bethesda, USA.

Received: 26 October 2020 Accepted: 31 March 2021

Published online: 14 June 2021

\section{References}

1. James SL, Abate D, Abate KH, Abay SM, Abbafati C, Abbasi N, et al. Global, regional, and national incidence, prevalence, and years lived with disability for 354 diseases and injuries for 195 countries and territories, 1990-2017: a systematic analysis for the Global Burden of Disease Study 2017. Lancet. 2018;392(10159):1789-858.

2. United Kingdom - England Hospital Episode Statistics (HES) | GHDx . [cited 2020 Mar 6]. Available from: http://ghdx.healthdata.org/series/unitedkingdom-england-hospital-episode-statistics-hes

3. United States Nationwide Inpatient Sample / GHDx. [cited 2020 Mar 6]. Available from: http://ghdx.healthdata.org/series/united-states-nationwideinpatient-sample

4. He Y, Lin GY, Wang Q, Cai XY, Zhang YH, Lin CX, et al. A 3-year prospective study of the epidemiology of acute respiratory viral infections in hospitalized children in Shenzhen, China. Influenza Other Respir Viruses. 2014;8(4):443-51.

5. Zhang Q, Guo Z, Bai Z, MacDonald NE. A 4 year prospective study to determine risk factors for severe community acquired pneumonia in children in southern China. IPediatr Pulmonoli. 2013;48(4):390-7.

6. Lindblade KA, Arvelo W, Gray J, Estevez A, Frenkel G, Reyes L, et al. A comparison of the epidemiology and clinical presentation of seasonal influenza A and 2009 pandemic influenza A (H1N1) in Guatemala. IPLoS Onei. 2010;5(12):15826.

7. Hammitt LL, Kazungu S, Morpeth SC, Gibson DG, Mvera B, Brent AJ, et al. A preliminary study of pneumonia etiology among hospitalized children in Kenya. IClin Infect Disi. 2012;54(Supp 2):190-9.

8. Maruyama T, Niederman MS, Kobayashi T, Kobayashi H, Takagi T, D'Alessandro-Gabazza CN, et al. A prospective comparison of nursing home-acquired pneumonia with hospital-acquired pneumonia in nonintubated elderly. IRespir Medi. 2008;102(9):1287-95.

9. Vong S, Guillard B, Borand L, Rammaert B, Goyet S, Te V, et al. Acute lower respiratory infections in 5 year -old hospitalized patients in Cambodia, a low-income tropical country: clinical characteristics and pathogenic etiology. IBMC Infect Disi. 2013;97.

10. Hijazi Z, Pacsa A, El-Gharbawy F, Chugh TD, Essa S, El Shazli A, et al. Acute lower respiratory tract infections in children in Kuwait. IAnn Trop Paediatri. 1997;17(2):127-34

11. Rahman M, Huq F, Sack DA, Butler T, Azad AK, Alam A, et al. Acute lower respiratory tract infections in hospitalized patients with diarrhea in Dhaka. Bangladesh IRev Infect Disi. 1990;12(Suppl 8):899-906.

12. Guerrier G, Goyet S, Chheng ET, Rammaert B, Borand L, Te V, et al. Acute viral lower respiratory tract infections in Cambodian children: clinical and epidemiologic characteristics. IPediatr Infect Ji. 2013;32(1):8-13.

13. García CS, Docón AM, Piñero JA, Miguelez SA, Bendicho MAl. Aetiology of bronchiolitis in hospitalised children in South-East Spain. IAn Pediatr Barci. 2012;77(6):386-90.

14. Sangil A, Calbo E, Robles A, Benet S, Viladot ME, Pascual V, et al. Aetiology of community-acquired pneumonia among adults in an H1N1 pandemic year: the role of respiratory viruses. IEur J Clin Microbiol Infect Disi. 2012; 31(10):2765-72

15. Quandelacy TM, Viboud C, Charu V, Lipsitch M, Goldstein E. Age- and sexrelated risk factors for influenza-associated mortality in the United States between 1997-2007. IAm J Epidemioli. 2014;179(2):156-67.

16. Gowin E, Bartkowska-Sniatkowska A, Jonczyk-Potoczna K, WysockaLeszczynska J, Bobkowski W, Fichna P, et al. Assessment of the usefulness of multiplex real-time PCR tests in the diagnostic and therapeutic process of pneumonia in hospitalized children: a single-center experience. Biomed Res Int. 2017:2017:8037963

17. Nascimento-Carvalho CM, Araujo-Neto CA, Ruuskanen O. Association between bacterial infection and radiologically confirmed pneumonia among children. IPediatr Infect Ji. 2015;34(5):490-3.

18. Grijalva CG, Zhu Y, Williams DJ, Self WH, Ampofo K, Pavia AT, et al. Association between hospitalization with community-acquired laboratory- 
confirmed influenza pneumonia and prior receipt of influenza vaccination. JAMA. 2015;314(14):1488-97.

19. Wolf DG, Greenberg D, Shemer-Avni Y, Givon-Lavi N, Bar-Ziv J, Dagan R. Association of human metapneumovirus with radiologically diagnosed community-acquired alveolar pneumonia in young children. IJ Pediatri. 2010;156(1):115-20.

20. Kelly MS, Smieja M, Luinstra K, Wirth KE, Goldfarb DM, Steenhoff AP, et al. Association of respiratory viruses with outcomes of severe childhood pneumonia in Botswana. IPLoS Onei. 2015;10(5):0126593.

21. Reechaipichitkul W, Thavornpitak Y, Sutra S. Burden of adult pneumonia in Thailand: a nationwide hospital admission data 2010. IJ Med Assoc Thaii. 2014;97(3):283-92.

22. Tran DN, Trinh QD, Pham NTK, Vu MP, Ha MT, Nguyen TQN, et al. Clinical and epidemiological characteristics of acute respiratory virus infections in Vietnamese children. IEpidemiol Infecti. 2015:1-10.

23. Lee JE, Choe K-W, Lee SW. Clinical and radiological characteristics of 2009 H1N1 influenza associated pneumonia in young male adults. IYonsei Med Ji. 2013;54(4):927-34.

24. Galindo-Fraga A, Ortiz-Hernandez AA, Ramírez-Venegas A, Vazquez RV, Moreno-Espinosa S, Llamosas-Gallardo B, et al. Clinical characteristics and outcomes of influenza and other influenza-like illnesses in Mexico City. Int J Infect Disi. 2013;17(7):510-7.

25. Ishida T, Tachibana H, Ito A, Tanaka M, Tokioka F, Furuta K, et al. Clinical characteristics of severe community-acquired pneumonia among younger patients: an analysis of 18 years at a community hospital. IJ Infect Chemotheri. 2014;20(8):471-6.

26. Hong KW, Cheong HJ, Choi WS, Lee J, Wie SH, Baek JH, et al. Clinical courses and outcomes of hospitalized adult patients with seasonal influenza in Korea, 2011-2012: hospital-based Influenza morbidity \& mortality (HIMM) surveillance. IJ Infect Chemotheri. 2014;20(1):9-14.

27. Mathur S, Dubey T, Kulshrestha M, Agarwal H, Mathur G, Mathur A, et al. Clinical profile and mortality among novel influenza A (H1N1) infected patients: 2009-2010 Jodhpur, Rajasthan pandemic. IJ Assoc Physicians Indiai. 2013;61(9):627-32.

28. Singh V, Sharma BB, Patel V, Poonia S. Clinical profile of pneumonia and its association with rain wetting in patients admitted at a tertiary care institute during pandemic of influenza A (H1N1) pdm09 virus infection. Indian J Chest Allied Scii. 2014;56(1):21-6.

29. Hara K, Yahara K, Gotoh K, Nakazono Y, Kashiwagi T, Imamura Y, et al. Clinical study concerning the relationship between community-acquired pneumonia and viral infection in northern Thailand. Inntern Medi. 2011;50(9): 991-8.

30. Maruyama T, Gabazza EC, Morser J, Takagi T, D'Alessandro-Gabazza C, Hirohata S, et al. Community-acquired pneumonia and nursing homeacquired pneumonia in the very elderly patients. IRespir Medi. 2010;104(4): 584-92.

31. Viasus D, Marinescu C, Villoslada A, Cordero E, Galvez-Acebal J, Farinas MC, et al. Community-acquired pneumonia during the first post-pandemic influenza season: a prospective, multicentre cohort study. IJ Infecti. 2013; 67(3):185-93.

32. Jain $\mathrm{S}$, Self WH, Wunderink RG, Fakhran $\mathrm{S}$, Balk R, Bramley AM, et al. Community-acquired pneumonia requiring hospitalization among U.S. adults. Engl J Medi. 2015;373(5):415-27.

33. Peci A, Winter AL, Gubbay JB, Skowronski DM, Balogun El, De Lima C, et al. Community-acquired respiratory viruses and co-infection among patients of Ontario sentinel practices. Influenza Other Respir Viruses. 2009; 7:559-66.

34. Hoo Lee J, Hyung KY. Comparison of clinical characteristics between healthcare-associated pneumonia and community-acquired pneumonia in patients admitted to secondary hospitals. Braz I Infect Dis Off Publ Braz Soc Infect Dis. 2012 Aug;16(4):321-8.

35. Papenburg J, Hamelin ME, Ouhoummane N, Carbonneau J, Ouakki M, Raymond F, et al. Comparison of risk factors for human metapneumovirus and respiratory syncytial virus disease severity in young children. IJ Infect Disi. 2012;206(2):178-89.

36. Gern JE, Pappas T, Visness CM, Jaffee KF, Lemanske RF, Togias A, et al. Comparison of the etiology of viral respiratory illnesses in inner-city and suburban infants. IJ Infect Disi. 2012;206(9):1342-9.

37. Li QH, Gao WJ, Li JY, Shi LA, Hao XJ, Ge SW, et al. Detection of respiratory viruses in children with acute lower respiratory tract infection: an analysis of 5,150 children. IChin J Contemp Pediatri. 2016;18(1):51-4.
38. Woolpert T, Brodine S, Lemus H, Waalen J, Blair P, Faix D. Determination of clinical and demographic predictors of laboratory-confirmed influenza with subtype analysis. IBMC Infect Disi. 2012;12:129.

39. Moreno L, Krishnan JA, Duran P, Ferrero F. Development and validation of a clinical prediction rule to distinguish bacterial from viral pneumonia in children. IPediatr Pulmonoli. 2006:41(4):331-7.

40. Levy NS, Nguyen TQ, Westheimer E, Layton M. Disparities in the severity of influenza illness: a descriptive study of hospitalized and nonhospitalized novel H1N1 influenza-positive patients in New York City: 2009-2010 influenza season. IJ Public Health Manag Practi. 2013;19(1):16-24.

41. Shu LH, Xu JJ, Wang S, Zhong HQ, Dong XY, Jiang K, et al. Distribution of pathogenic microorganisms and its relationship with clinical features in children with community-acquired pneumonia. IChin J Contemp Pediatri. 2015;17(10):1056-61

42. Guo RN, Zheng $H Z$, Huang LQ, Zhou Y, Zhang $X$, Liang CK, et al. Epidemiologic and economic burden of influenza in the outpatient setting: a prospective study in a subtropical area of China. IPLoS Onei. 2012;7(7): 41403.

43. Li H, Wei Q, Tan A, Wang L. Epidemiological analysis of respiratory viral etiology for influenza-like illness during 2010 in Zhuhai, China. IVirol Ji. 2013; 143.

44. Sung RYT, Cheng AFB, Chan RCK, Tam JS, Oppenheimer SJ. Epidemiology and Etiology of Pneumonia in Children in Hong Kong. IClin Infect Disi. 1993; 17(5):894-6.

45. Khor CS, Sam IC, Hooi PS, Quek KF, Chan YF. Epidemiology and seasonality of respiratory viral infections in hospitalized children in Kuala Lumpur, Malaysia: a retrospective study of 27 years. IBMC Pediatri. 2012;12:32.

46. Minodier L, Arena C, Heuze G, Ruello M, Amoros JP, Souty C, et al. Epidemiology and viral etiology of the influenza-like illness in corsica during the 2012-2013 Winter: an analysis of several sentinel surveillance systems. IPLoS Onei. 2014;9(6):100388.

47. Liu WK, Liu Q, Chen DH, Liang HX, Chen XK, Chen MX, et al. Epidemiology of acute respiratory infections in children in Guangzhou: a three-year study. IPLoS Onei. 2014;9(5):96674.

48. Kim JK, Jeon JS, Kim JW, Rheem I. Epidemiology of respiratory viral infection using multiplex rt-PCR in Cheonan, Korea (2006-2010). IJ Microbiol Biotechnoli. 2013;23(2):267-73.

49. Vallés J, Martin-Loeches I, Torres A, Diaz E, Seijas I, López MJ, et al. Epidemiology, antibiotic therapy and clinical outcomes of healthcareassociated pneumonia in critically ill patients: a Spanish cohort study. IIntensive Care Medi. 2014;40(4):572-81.

50. Koksal I, Bayraktar O, Yilmaz G, Caylan R, Aydin K, Sucu N, et al. Etiological agents of community-acquired pneumonia in adult patients in Turkey; a multicentric, cross-sectional study. ITuberk Toraksi. 2010;58(2):119-27.

51. Liu YF, Gao Y, Chen MF, Cao B, Yang XH, Wei L. Etiological analysis and predictive diagnostic model building of community-acquired pneumonia in adult outpatients in Beijing, China. IBMC Infect Disi. 2013;13:309.

52. Ferronato $A E$, Gilio $A E$, Ferraro $A A, M d P$, Vieira $S E$. Etiological diagnosis reduces the use of antibiotics in infants with bronchiolitis. Clinics (Sao Paulo). 2012;67:1001-6.

53. Yang X, Yao Y, Chen M, Yang X, Xie Y, Liu Y, et al. Etiology and clinical characteristics of influenza-like illness (ILI). Outpatients Beijing. PLoS One. 2010;7(1):28786

54. Yu X, Lu R, Wang Z, Zhu N, Wang W, Julian D, et al. Etiology and clinical characterization of respiratory virus infections in adult patients attending an emergency department in Beijing. IPLoS Onei. 2012;7(2):32174.

55. Tajima T, Nakayama E, Kondo Y, Hirai F, Ito H, litsuka T, et al. Etiology and clinical study of community-acquired pneumonia in 157 hospitalized children. IJ Infect Chemotheri. 2006;12(6):372-9.

56. O'Callaghan-Gordo C, Bassat Q, Morais L, Díez-Padrisa N, Machevo S, Nhampossa T, et al. Etiology and epidemiology of viral pneumonia among hospitalized children in rural Mozambique: a malaria endemic area with high prevalence of human immunodeficiency virus. IPediatr Infect Ji. 2011; 30(1):39-44.

57. Ishiguro T, Takayanagi N, Yamaguchi S, Yamakawa H, Nakamoto K, Takaku Y, et al. Etiology and factors contributing to the severity and mortality of community-acquired pneumonia. Intern Medi. 2013;52(3): $317-24$.

58. Schlaudecker EP, Heck JP, Macintyre ET, Martinez R, Dodd CN, McNeal MM, et al. Etiology and seasonality of viral respiratory infections in rural Honduran children. IPediatr Infect Ji. 2012;31(11):1113-8. 
59. Tupasi TE, Lucero MG, Magdangal DM, Mangubat NV, Sunico ME, Torres CU, et al. Etiology of acute lower respiratory tract infection in children from Alabang, Metro Manila. IRev Infect Disi. 1990;12(Suppl 8):929-39.

60. Forgie IM, O'Neill KP, Lloyd-Evans N, Leinonen M, Campbell H, Whittle HC, et al. Etiology of acute lower respiratory tract infections in Gambian children: I Acute lower respiratory tract infections in infants presenting at the hospital. IPediatr Infect Ji. 1991;10(1):33-41.

61. Forgie IM, O'Neill KP, Lloyd-Evans N, Leinonen M, Campbell H, Whittle HC, et al. Etiology of acute lower respiratory tract infections in Gambian children: II Acute lower respiratory tract infection in children ages one to nine years presenting at the hospital. IPediatr Infect Ji. 1991;10(1):42-7.

62. John TJ, Cherian T, Steinhoff MC, Simoes EA, John M. Etiology of acute respiratory infections in children in tropical southern India. IRev Infect Disi. 1991;13(Suppl 6):463-9.

63. Holter JC, Muller F, Bjorang O, Samdal HH, Marthinsen JB, Jenum PA, et al. Etiology of community-acquired pneumonia and diagnostic yields of microbiological methods: a 3-year prospective study in Norway. IBMC Infect Disi. 2015;15:64.

64. Shibli F, Flatau E, Nitzan O, Chazan B, Edelstein H, Raz R, et al. Etiology of community-acquired pneumonia in hospitalized patients in Northern Israel. Ilsr Med Assoc Ji. 2010;12(8):477-82.

65. Johansson N, Kalin M, Tiveljung-Lindell A, Giske CG, Hedlund J. Etiology of community-acquired pneumonia: increased microbiological yield with new diagnostic methods. IClin Infect Disi. 2010;50(2):202-9.

66. Hartung TK, Chimbayo D, Oosterhout JJG, Chikaonda T, Doornum GJJ, Claas ECJ, et al. Etiology of suspected pneumonia in adults admitted to a highdependency unit in Blantyre. Malawi IAm J Trop Med Hygi. 2011;85(1):105-12.

67. Lin Y, Fu Y, Xu M, Su L, Cao L, Xu J, et al. Evaluation of a PCR/ESI-MS platform to identify respiratory viruses from nasopharyngeal aspirates. IJ Med Viroli. 2015:87(11):1867-71.

68. Kelly PM, Kotsimbos T, Reynolds A, Wood-Baker R, Hancox B, Brown SGA, et al. FluCAN 2009: initial results from sentinel surveillance for adult influenza and pneumonia in eight Australian hospitals. IMed J Austi. 2011; 194(4):169-74.

69. Monto AS, Malosh RE, Petrie JG, Thompson MG, Ohmit SE. Frequency of acute respiratory illnesses and circulation of respiratory viruses in households with children over 3 surveillance seasons. IJ Infect Disi. 2014; 210(11):1792-9.

70. Hernandez-Bou S, Novell CB, Alins JG, García-García JJ. Hospitalized children with influenza A H1N1 (2009) infection: a Spanish multicenter study. IPediatr Emerg Carei. 2013;29(1):49-52.

71. von Baum H, Schweiger B, Welte T, Marre R, Suttorp N, Pletz MWR, et al. How deadly is seasonal influenza-associated pneumonia? The German Competence Network for Community-Acquired Pneumonia. IEur Respir Ji. 2011;37(5):1151-7.

72. Lu G, Li J, Xie Z, Liu C, Guo L, Vernet G, et al. Human metapneumovirus associated with community-acquired pneumonia in children in Beijing, China. IJ Med Viroli. 2013;85(1):138-43.

73. Sung RYT, Chan PKS, Tsen T, Li AM, Lam WY, Yeung ACM, et al. Identification of viral and atypical bacterial pathogens in children hospitalized with acute respiratory infections in Hong Kong by multiplex PCR assays. IJ Med Viroli. 2009;81 (1):153-9.

74. Hasan R, Rhodes J, Thamthitiwat S, Olsen SJ, Prapasiri P, Naorat S, et al. Incidence and etiology of acute lower respiratory tract infections in hospitalized children younger than 5 years in rural Thailand. IPediatr Infect Ji. 2014;33(2):45-52.

75. Palmu AA, Saukkoriipi A, Snellman M, Jokinen J, Torkko P, Ziegler T, et al. Incidence and etiology of community-acquired pneumonia in the elderly in a prospective population-based study. IScand J Infect Disi. 2014;46(4):250-9.

76. Piralam B, Tomczyk SM, Rhodes JC, Thamthitiwat S, Gregory CJ, Olsen SJ, et al. Incidence of Pneumococcal Pneumonia Among Adults in Rural Thailand, 2006-2011: Implications for Pneumococcal Vaccine Considerations. IAm J Trop Med Hygi. 2015;93(6):1140-7.

77. Olsen SJ, Thamthitiwat S, Baggett HC, Maloney S, Peruski LF, Chantra S, et al. Incidence of respiratory pathogens in persons hospitalized with pneumonia in two provinces in Thailand. IEpidemiol Infecti. 2010;138(12):1811-22.

78. Homaira N, Luby SP, Petri WA, Vainionpaa R, Rahman M, Hossain K, et al. Incidence of respiratory virus-associated pneumonia in urban poor young children of Dhaka, Bangladesh, 2009-2011. 2009;7:32056.

79. Wiemken T, Peyrani P, Bryant K, Kelley RR, Summersgill J, Arnold F, et al. Incidence of respiratory viruses in patients with community-acquired pneumonia admitted to the intensive care unit: results from the Severe Influenza Pneumonia Surveillance (SIPS) project. IEur J Clin Microbiol Infect Disi. 2013;32(5):705-10.

80. Marcone DN, Durand LO, Azziz-Baumgartner E, Vidaurreta S, Ekstrom J, Carballal $G$, et al. Incidence of viral respiratory infections in a prospective cohort of outpatient and hospitalized children aged $\leq 5$ years and its associated cost in Buenos Aires, Argentina. IBMC Infect Disi. 2015;15:447.

81. Lahti E, Peltola V, Waris M, Virkki R, Rantakokko-Jalava K, Jalava J, et al. Induced sputum in the diagnosis of childhood community-acquired pneumonia. Thorax. 2009;64(3):252-7.

82. Mardy S, Ly S, Heng S, Vong S, Huch C, Nora C, et al. Influenza activity in Cambodia during 2006-2008. IBMC Infect Disi. 2009;9:168.

83. Zimmerman RK, Rinaldo CR, Nowalk MP, Gk B, Thompson MG, Moehling KK, et al. Influenza and other respiratory virus infections in outpatients with medically attended acute respiratory infection during the 2011-12 influenza season. IInfluenza Respir Virusesi. 2014;8(4):397-405.

84. Laguna-Torres VA, Sánchez-Largaespada JF, Lorenzana I, Forshey B, Aguilar $P$, Jimenez $M$, et al. Influenza and other respiratory viruses in three Central American countries. IInfluenza Respir Virusesi. 2011;5(2):123-34.

85. Onyango CO, Njeru R, Kazungu S, Achilla R, Bulimo W, Welch CSR, et al. Influenza surveillance among children with pneumonia admitted to a district hospital in coastal Kenya, 2007-2010. IJ Infect Disi. 2012;206(Suppl 1):61-7.

86. Radin JM, Katz MA, Tempia S, Talla Nzussouo N, Davis R, Duque J, et al. Influenza surveillance in 15 countries in Africa, 2006-2010. J Infect Dis. 2012; 206:14-21.

87. Tessmer A, Welte T, Schmidt-Ott R, Eberle S, Barten G, Suttorp N, et al. Influenza vaccination is associated with reduced severity of communityacquired pneumonia. IEur Respir Ji. 2011;38(1):147-53.

88. Mermond S, Zurawski V, D’Ortenzio E, Driscoll AJ, DeLuca AN, Deloria-Knoll $M$, et al. Lower respiratory infections among hospitalized children in New Caledonia: a pilot study for the Pneumonia Etiology Research for Child Health project. IClin Infect Disi. 2012;54:180-9.

89. Martín-Loeches I, Bermejo-Martin JF, Vallés J, Granada R, Vidaur L, VergaraSerrano JC, et al. Macrolide-based regimens in absence of bacterial coinfection in critically ill H1N1 patients with primary viral pneumonia. Intensive Care Medi. 2013:39(4):693-702.

90. Sundaram ME, Meece JK, Sifakis F, Gasser RA, Belongia EA. Medically attended respiratory syncytial virus infections in adults aged? 50 years: clinical characteristics and outcomes. IClin Infect Disi. 2014;58(3):342-9.

91. Henrickson KJ, Hoover S, Kehl KS, Hua W. National disease burden of respiratory viruses detected in children by polymerase chain reaction. IPediatr Infect Ji. 2004;23(1 Suppl):11-8.

92. Lynfield R, Davey R, Dwyer DE, Losso MH, Wentworth D, Cozzi-Lepri A, et al. Outcomes of influenza $A(\mathrm{H} 1 \mathrm{~N} 1)$ pdm09 virus infection: results from two international cohort studies. IPLoS Onei. 2014;9(7):101785.

93. Fitter DL, Freeman NM, Buteau J, Magloire R, Sessions WM, Guo L, et al. Pandemic H1N1 influenza surveillance in Haiti, July-December 2009 IInfluenza Respir Virusesi. 2013;7(5):772-5.

94. Peng Y, Shu C, Fu Z, Li QB, Liu Z, Yan L. Pathogen detection of 1613 cases of hospitalized children with community acquired pneumonia. IChin J Contemp Pediatri. 2015;17(11):1193-9.

95. Williams JV, Edwards KM, Weinberg GA, Griffin MR, Hall CB, Zhu Y, et al. Population-based incidence of human metapneumovirus infection among hospitalized children. IJ Infect Disi. 2010;201(12):1890-8.

96. Nasreen S, Luby SP, Brooks WA, Homaira N, Al Mamun A, Bhuiyan MU, et al. Population-based incidence of severe acute respiratory virus infections among children aged <5 years in rural Bangladesh. PLoS One. 2010;9(2):89978.

97. Weigl JA, Puppe W, Belke O, Neusüss J, Bagci F, Schmitt HJ. Populationbased incidence of severe pneumonia in children in Kiel. Ger IKlin Padiatri. 2005;217(4):211-9.

98. Hon KL, Leung E, Hung E, Tang J, Chow CM, Leung TF, et al. Premorbid factors and outcome associated with respiratory virus infections in a pediatric intensive care unit. IPediatr Pulmonoli. 2008;43(3):275-80.

99. Samransamruajkit R, Hiranrat T, Chieochansin T, Sritippayawan $\mathrm{S}$, Deerojanawong J, Prapphal N, et al. Prevalence, clinical presentations and complications among hospitalized children with influenza pneumonia. IJpn J Infect Disi. 2008;61(6):446-9.

100. Song JY, Lee JS, Wie SH, Kim HY, Lee J, Seo YB, et al. Prospective cohort study on the effectiveness of influenza and pneumococcal vaccines in preventing pneumonia development and hospitalization. IClin Vaccine Immunoli. 2015;22(2):229-34. 
101. Pretorius MA, Madhi SA, Cohen C, Naidoo D, Groome M, Moyes J, et al. Respiratory viral coinfections identified by a 10-plex real-time reversetranscription polymerase chain reaction assay in patients hospitalized with severe acute respiratory illness-South Africa, 2009-2010. IJ Infect Disi. 2012; 206:159-65.

102. Self WH, Williams DJ, Zhu Y, Ampofo K, Pavia AT, Chappell JD, et al. Respiratory viral detection in children and adults: comparing asymptomatic controls and patients with community-acquired pneumonia. IJ Infect Disi. 2016;213(4):584-91.

103. Herrera-Rodríguez DH, Hoz F, Mariño C, Ramírez E. Respiratory virus in children aged less than 10 years old suffering from respiratory infection in the Hospital Militar Central in Bogota from 2000-2001. IRev Salud Publica Bogotai. 2007:9(4):576-86.

104. Sentilhes AC, Choumlivong K, Celhay O, Sisouk T, Phonekeo D, Vongphrachanh $\mathrm{P}$, et al. Respiratory virus infections in hospitalized children and adults in Lao PDR. IInfluenza Respir Virusesi. 2013;7(6):1070-8.

105. Suzuki A, Lupisan S, Furuse Y, Fuji N, Saito M, Tamaki R, et al. Respiratory viruses from hospitalized children with severe pneumonia in the Philippines. IBMC Infect Disi. 2012;12:267.

106. Lieberman D, Shimoni A, Shemer-Avni Y, Keren-Naos A, Shtainberg R, Lieberman $D$. Respiratory viruses in adults with community-acquired pneumonia. Chest. 2010;138(4):811-6.

107. Kwofie TB, Anane YA, Nkrumah B, Annan A, Nguah SB, Owusu M. Respiratory viruses in children hospitalized for acute lower respiratory tract infection in Ghana. IVirol Ji. 2012;9:78.

108. Mathisen M, Strand TA, Valentiner-Branth P, Chandyo RK, Basnet S, Sharma $\mathrm{BN}$, et al. Respiratory viruses in nepalese children with and without pneumonia: a case-control study. IPediatr Infect Ji. 2010;29(8):731-5.

109. Teeratakulpisarn J, Pientong C, Ekalaksananan T, Ruangsiripiyakul H, Uppala $R$. Rhinovirus infection in children hospitalized with acute bronchiolitis and its impact on subsequent wheezing or asthma: a comparison of etiologies. IAsian Pac J Allergy Immunoli. 2014;32(3):226-34.

110. Zolotusca L, Jorgensen P, Popovici O, Pistol A, Popovici F, Widdowson MA et al. Risk factors associated with fatal influenza, Romania, October 2009May 2011. Influenza Other Respir Viruses. 2014;8:8-12.

111. Zhang PJ, Cao B, Li XL, Liang LR, Yang SG, Gu L, et al. Risk factors for adult death due to 2009 pandemic influenza A (H1N1) virus infection: a 2151 severe and critical cases analysis. IChin Med J Engli. 2013;126(12): 2222-8.

112. Mathisen M, Strand TA, Sharma BN, Chandyo RK, Valentiner-Branth P, Basnet $\mathrm{S}$, et al. RNA viruses in community-acquired childhood pneumonia in semiurban Nepal; a cross-sectional study. IBMC Medi. 2009;7:35.

113. Mathisen M, Basnet S, Sharma A, Shrestha PS, Sharma BN, Valentiner-Branth $P$, et al. RNA viruses in young Nepalese children hospitalized with severe pneumonia. IPediatr Infect Ji. 2011;30(12):1032-6.

114. Litwin CM, Bosley JG. Seasonality and prevalence of respiratory pathogens detected by multiplex PCR at a tertiary care medical center. IArch Viroli. 2014;159(1):65-72.

115. Tamfum JJM, Nkwembe E, Shamamba SKB, Bankoshi F, llunga BK, Katz KA et al. Sentinel surveillance for influenza-like illness, severe acute respiratory illness, and laboratory-confirmed influenza in Kinshasa, Democratic Republic of Congo, 2009-2011. J Infect Dis. 2012;206:36-40.

116. Suryaprasad A, Redd JT, Hancock K, Branch A, Steward-Clark E, Katz JM, et al. Severe acute respiratory infections caused by 2009 pandemic influenza A (H1N1) among American Indians-southwestern United States, May 1-July 21, 2009. IInfluenza Respir Viruses. 2013;7(6):1361-9.

117. Nicolae O, Popovici F, Lupulescu E, Ivanciuc AE, Necula G. Severe acute respiratory infections surveillance in Romania - is it any gain to public health? Med Surg J Soc Phys Nat lasii. 2012;116(4):1185-91.

118. Mistry RD, Fischer JB, Prasad PA, Coffin SE, Alpern ER. Severe complications in influenza-like illnesses. Pediatrics. 2014;134(3):684-90.

119. Tecu C, Mihai ME, Alexandrescu OVI, Orășeanu D, Zapucioiu C, Ivanciuc AE, et al. Single and multipathogen viral infections in hospitalized children with acute respiratory infections. IRoum Arch Microbiol Immunoli. 2013;72(4): 242-9.

120. Narvaez-Rivera RM, Rendon A, Salinas-Carmona MC, Rosas-Taraco AG. Soluble RAGE as a severity marker in community acquired pneumonia associated sepsis. IBMC Infect Disi. 2012;12:15.

121. Garcia-Garcia ML, Calvo C, Pozo F, Villadangos PA, Perez-Brena P, Casas I. Spectrum of respiratory viruses in children with community-acquired pneumonia. IPediatr Infect Ji. 2012;31(8):808-13.
122. Verani MJR, McCracken J, Arvelo W, Estevez A, Lopez MR, et al. Surveillance for hospitalized acute respiratory infection in Guatemala. IPLoS Onei. 2013; $8(12): 83600$

123. Ndegwa LK, Katz MA, McCormick K, Nganga Z, Mungai A, Emukule G, et al. Surveillance for respiratory health care-associated infections among inpatients in 3 Kenyan hospitals, 2010-2012. IAm J Infect Controli. 2014;42(9): 985-90.

124. Guan WD, Gong XY, Mok CK, Chen TT, Wu SG, Pan SH, et al. Surveillance for seasonal influenza virus prevalence in hospitalized children with lower respiratory tract infection in Guangzhou, China during the post-pandemic era. IPLoS Onei. 2015;10(4):0120983.

125. Huo X, Qin Y, Qi X, Zu R, Tang F, Li L, et al. Surveillance of 16 respiratory viruses in patients with influenza-like illness in Nanjing, China. IJ Med Viroli. 2012;84(12):1980-4.

126. Guatura SB, Watanabe AS, Camargo CN, Passos AM, Parmezan SN, Tomazella TK, et al. Surveillance of influenza A H1N1 2009 among school children during 2009 and 2010 in São Paulo. Braz IRev Soc Bras Med Tropi. 2012;45(5):563-6.

127. Morimoto K, Suzuki M, Ishifuji T, Yaegashi M, Asoh N, Hamashige N, et al. The burden and etiology of community-onset pneumonia in the aging Japanese population: a multicenter prospective study. IPLoS Onei. 2015; 10(3):0122247.

128. Storms AD, Kusriastuti R, Misriyah S, Praptiningsih CY, Amalya M, Lafond KE, et al. The East Jakarta Project: surveillance for highly pathogenic avian influenza $\mathrm{A}(\mathrm{H} 5 \mathrm{~N} 1)$ and seasonal influenza viruses in patients seeking care for respiratory disease, Jakarta, Indonesia, October 2011-September 2012. Epidemiol Infect. 2015;143:3394-404.

129. Peng J, Kong W, Guo D, Liu M, Wang Y, Zhu H, et al. The epidemiology and etiology of influenza-like illness in Chinese children from 2008 to 2010. IJ Med Viroli. 2012:84(4):672-8

130. Nascimento-Carvalho CM, Ribeiro CT, Viriato D, Souza AL, Cardoso MRA, Barral A, et al. The role of respiratory viral infections among children hospitalized for community-acquired pneumonia in a developing country. Pediatr Infect Ji. 2008;27(10):939-41.

131. McMorrow ML, Emukule GO, Njuguna HN, Bigogo G, Montgomery JM, Nyawanda B, et al. The unrecognized burden of influenza in young Kenyan children, 2008-2012. IPLoS Onei. 2015;10(9):0138272.

132. Thiberville SD, Ninove L, Vu Hai V, Botelho-Nevers E, Gazin C, Thirion L, et al. The viral etiology of an influenza-like illness during the 2009 pandemic. IJ Med Viroli. 2012;84(7):1071-9.

133. Moore HC, Klerk N, Keil AD, Smith DW, Blyth CC, Richmond P, et al. Use of data linkage to investigate the aetiology of acute lower respiratory infection hospitalisations in children. IJ Paediatr Child Heal. 2012;48(6):520-8.

134. Zhang Q, MacDonald NE, Guo Z. Vaccine preventable community-acquired pneumonia in hospitalized children in Northwest China. IPediatr Infect Ji. 2011;30(1):7-10.

135. Puig-Barbera J, Mira-Iglesias A, Tortajada-Girbes M, Lopez-Labrador FX, Belenguer-Varea A, Carballido-Fernandez M, et al. Valencia Hospital Network for the Study of Influenza and Respiratory Viruses Disease. Effectiveness of influenza vaccination programme in preventing hospital admissions, Valencia, 2014/15 early results. IEuro Surveilli. 2015;20(8): 21044.

136. Gupta V, Dawood FS, Rai SK, Broor S, Wigh R, Mishra AC, et al. Validity of clinical case definitions for influenza surveillance among hospitalized patients: results from a rural community in North India. IInfluenza Respir Virusesi. 2013;7(3):321-9.

137. Singh AK, Jain A, Jain B, Singh KP, Dangi T, Mohan M, et al. Viral aetiology of acute lower respiratory tract illness in hospitalised paediatric patients of a tertiary hospital: one year prospective study. Inndian J Med Microbioli. 2014; 32(1):13-8.

138. Hoffmann J, Rabezanahary H, Randriamarotia M, Ratsimbasoa A, Najjar J, Vernet $\mathrm{G}$, et al. Viral and atypical bacterial etiology of acute respiratory infections in children under 5 years old living in a rural tropical area of Madagascar. IPLoS Onei. 2012;7(8):43666.

139. Feikin DR, Njenga MK, Bigogo G, Aura B, Aol G, Audi A, et al. Viral and bacterial causes of severe acute respiratory illness among children aged less than 5 years in a high malaria prevalence area of western Kenya, 2007-2010. Pediatr Infect Dis J. 2013;32(1):e14-9.

140. Laurent C, Dugue AE, Brouard J, Nimal D, Dina J, Parienti JJ, et al. Viral epidemiology and severity of respiratory infections in infants in 2009: a prospective study. IPediatr Infect Ji. 2012;31(8):827-31. 
141. Feng L, Li Z, Zhao S, Nair H, Lai S, Xu W, et al. Viral etiologies of hospitalized acute lower respiratory infection patients in China, 2009-2013. IPLoS Onei. 2014;9(6):99419.

142. Feng L, Lai S, Li F, Ye X, Li S, Ren X, et al. Viral etiologies of hospitalized pneumonia patients aged less than five years in six provinces, 2009-2012. IChin J Epidemioli. 2014;35(6):646-9.

143. Miller EK, Gebretsadik T, Carroll KN, Dupont WD, Mohamed YA, Morin LL, et al. Viral etiologies of infant bronchiolitis, croup and upper respiratory illness during 4 consecutive years. IPediatr Infect Ji. 2013;32(9):950-5.

144. Shafik CF, Mohareb EW, Yassin AS, Amin MA, El Kholy A, El-Karaksy H, et al. Viral etiologies of lower respiratory tract infections among Egyptian children under five years of age. IBMC Infect Disi. 2012;350.

145. Zhang C, Zhu N, Xie Z, Lu R, He B, Liu C, et al. Viral etiology and clinical profiles of children with severe acute respiratory infections in China. IPLOS Onei. 2013:8(8):72606.

146. Huang G, Yu D, Mao N, Zhu Z, Zhang H, Jiang Z, et al. Viral etiology of acute respiratory infection in Gansu Province. Vol. 8. China; 2011. p. 64254

147. Marcone DN, Ellis A, Videla C, Ekstrom J, Ricarte C, Carballal G, et al. Viral etiology of acute respiratory infections in hospitalized and outpatient children in Buenos Aires, Argentina. IPediatr Infect Ji. 2013;32(3):105-10.

148. M Luisa Rioseco Z, Raúl Riquelme O, Mauricio Riquelme O, Carlos Inzunza P, Paola Oyarzún G, Yasna Agüero O, et al. Viral etiology of community acquired pneumonia among adults admitted to a general hospital. IRev Med Chili. 2012;140(8):984-9

149. Qu J-X, Gu L, Pu Z-H, Yu X-M, Liu Y-M, Li R, et al. Viral etiology of community-acquired pneumonia among adolescents and adults with mild or moderate severity and its relation to age and severity. IBMC Infect Disi. 2015;15:89.

150. Karadag-Oncel E, Ciblak MA, Ozsurekci Y, Badur S, Ceyhan M. Viral etiology of influenza-like illnesses during the influenza season between December 2011 and April 2012. IJ Med Viroli. 2014;86(5):865-71.

151. Njouom R, Yekwa EL, Cappy P, Vabret A, Boisier P, Rousset D. Viral etiology of influenza-like illnesses in Cameroon, January-December 2009. IJ Infect Disi. 2012;206:29-35.

152. Ju X, Fang Q, Zhang J, Xu A, Liang L, Ke C. Viral etiology of influenza-like illnesses in Huizhou, China, from 2011 to 2013. IArch Viroli. 2014;159(8):2003-10.

153. Hasan K, Jolly P, Marquis G, Roy E, Podder G, Alam K, et al. Viral etiology of pneumonia in a cohort of newborns till 24 months of age in Rural Mirzapur. Bangladesh IScand J Infect Disi. 2006;38(8):690-5.

154. Ouédraogo S, Traoré B, Nene Bi ZAB, Yonli FT, Kima D, Bonané $P$, et al. Viral etiology of respiratory tract infections in children at the pediatric hospital in Ouagadougou (Burkina Faso). IPLoS Onei. 2014;9(10):110435.

155. Yoshida LM, Suzuki M, Yamamoto T, Nguyen HA, Nguyen CD, Nguyen AT, et al. Viral pathogens associated with acute respiratory infections in central vietnamese children. IPediatr Infect Ji. 2010;29(1):75-7.

156. Honkinen M, Lahti E, Österback R, Ruuskanen O, Waris M. Viruses and bacteria in sputum samples of children with community-acquired pneumonia. IClin Microbiol Infecti. 2012;18(3):300-7.

157. Fowlkes A, Giorgi A, Erdman D, Temte J, Goodin K, Di Lonardo S, et al. Viruses associated with acute respiratory infections and influenza-like illness among outpatients from the Influenza Incidence Surveillance Project, 20102011. IJ Infect Disi. 2014;209(11):1715-25.

158. Kono J, Jonduo MH, Omena M, Siba PM, Horwood PF. Viruses associated with influenza-like-illnesses in Papua New Guinea. IJ Med Viroli. 2010;86(5): 899-904.

159. Ngeow YF, Weil AF, Khairullah NS, Yusof MY, Luam L, Gaydos C, et al. Young Malaysian children with lower respiratory tract infections show low incidence of chlamydial infection. IJ Paediatr Child Heal. 1997;33(5): 422-5.

160. Shi WY, Zhu WH, He ZG, Xu GZ, Li LP. Analysis of characteristics of pathogens in viral pneumonia [Chinese]. Med Inf. 2012;25(3):93.

161. Xie YP, Deng L. 1815 cases of lower respiratory infection in young children [Chinese]. Guangzhou Med J. 2011;42(3):24-6.

162. Okada T, Morozumi M, Sakata $H$, Takayanagi $R$, Ishiwada N, Sato $Y$, et al. A practical approach estimating etiologic agents using real-time PCR in pediatric inpatients with community-acquired pneumonia. J Infect Chemother. 2012 Dec;18(6):832-40.

163. Arnott A, Vong S, Mardy S, Chu S, Naughtin M, Sovann L, et al. A study of the genetic variability of human respiratory syncytial Virus (HRSV) in Cambodia reveals the existence of a new HRSV group B genotype. J Clin Microbiol. 2011 Oct;49(10):3504-13.
164. Wang FM, Luo YC, Zhu YY, Xu LD. A study of viral etiology of impatients below 5 years old with community acquired pneumonia in Wenzhou [Chinese]. Zhejiang Prev Med. 2011;23(2):17-9.

165. Zheng WJ. A study on etiology and clinial epidemiology of respiratory tract in children in Kunming area [Chinese] [Master]. Vol. MSc. Kunming Medical University; 2011.

166. Ye LF, Yuan CD. A study on etiology of acute lower respiratory tract infections in infants [Chinese]. Zhejiang Prev Med. 2004;16(8):5-6.

167. Cao L, Lu J, Qian Y, Chen HZ, Zhu NM, Deng J, et al. A viral etiological and clinical investigation into acute lower respiratory tract infection in children under 6 years old [Chinese]. Chin J Pract Pediatr. 2004;19(9): 528-31.

168. Santibanez P, Gooch K, Vo P, Lorimer M, Sandino Y. Acute care utilization due to hospitalizations for pediatric lower respiratory tract infections in British Columbia, Canada. BMC Health Serv Res. 2012:12:451.

169. Videla C, Carballal G, Misirlian A, Aguilar M. Acute lower respiratory infections due to respiratory syncytial virus and adenovirus among hospitalized children from Argentina. Clin Diagn Virol. 1998;10(1):17-23.

170. Siritantikorn S, Puthavathana P, Suwanjutha S, Chantarojanasiri T, Sunakorn $P$, Ratanadilok Na Phuket T, et al. Acute viral lower respiratory infections in children in a rural community in Thailand. J Med Assoc Thail. 2002;85(Suppl 4):S1167-75.

171. Richter J, Panayiotou C, Tryfonos C, Koptides D, Koliou M, Kalogirou N, et al. Aetiology of Acute Respiratory Tract Infections in Hospitalised Children in Cyprus. PLoS One. 2016;11(1):e0147041 Available from: //WOS:000368033100066 http://journals.plos.org/plosone/article/file?id= 10.1371/journal.pone.0147041\&type=printable.

172. Yin WY, Lu G, Su SS, Wang F. An analysis on respiratory seven virus detection results in sputum in 1050 children with capillary bronchitis [Chinese]. J Guiyang Med Coll. 2012;37(3):280-2.

173. Xie H, Li GC, Wang PP, Wu SZ, Luo ZY, Huang B, et al. An etiology investigation of acute lower respiratory tract infection in children in Chaozhou [Chinese]. Med Innov China. 2013;10(11):116-8.

174. Liang Y, Wang Y, Nan Y, Chen SQ. Analysis of 75 cases lower respiratory tract infection by respiratory syncytial virus [Chinese]. Chin J Perinat Med. 2012:15(4):206-10.

175. Ye YY, Li WC, Zhang N. Analysis of 374 hospitalised cases of respiratory infection [Chinese]. Chin J Rural Med Pharm. 2014;21(21):60-1.

176. Zhang YL, Lin HL, Lan JH, Qian LJ. Analysis of children hospitalised with respiratory syncytial virus associated with acute lower respiratory infection [Chinese]. Chin Pediatr Emerg Med. 2014;21(3):143-4

177. Liang $\mathrm{L}, \mathrm{Ge} R \mathrm{RH}$. Analysis of diagnosis of children with acute lower respiratory infection in Guiyang area during 2012 and 2013 [Chinese]. Guiyang Med. 2014;38(7):655-7.

178. Xue HF, Liu XP, Su WD. Analysis of epidemiology of 2813 cases with acute respiratory infection in children [Chinese]. Zhejiang J Integr Tradit Chin West Med. 2014:24(9):834-6.

179. Zhang L. Analysis of Etiological Agent in Hospitalized Children with Lower Respiratory infection in Cheng Du Area [Chinese] [Master]. Vol. MSc. Luzhou Medical College; 2008

180. He Y. Analysis of features of children with viral infection from outpatiens and inpatients during 2011 and 2012 [Chinese]. Matern Child Health Care China. 2015:30:382-4.

181. Min SJ, Song JS, Choi JH, Seon HS, Kang EK, Kim DH, et al. Analysis of palivizumab prophylaxis in patients with acute lower respiratory tract infection caused by respiratory syncytial virus. [Korean]. Korean J Pediatr Infect Dis. 2011;18(2):154-62.

182. Wang SM. Analysis of pathogens in children pneumonia [Chinese]. Med Inf. 2011;09:4262.

183. Che DD, Lu Q, Lu M, Ji F, Tong HY. Analysis of pathogens in children with acute lower respiratory infection in Shanghai in 2000 [Chinese]. Chin J Contemp Pediatr. 2004;6(2):136-8.

184. Yao J, Shen GS, Fan LH, Li WW. Analysis of viral pathogens among 6089 children hospitalised with respiratory infection [Chinese]. Chin J Epidemio 2015;36(6):664-6.

185. Fan M, Wu Q, Ni LX, Song SQ, Feng XX. Analysis of viral pathogens identified in children with lower respiratory infection in Kunming area [Chinese]. Chin J Child Heath Care. 2007:15(5):539-41.

186. Ding PB, Tian PJ. Analysis of viral pathogens in young children with lower respiratory infection in Ningxia district [Chinese]. Contemp Med. 2014;20(20): 159-60. 
187. Wang W, Lin SX, Li SY, ZHang H, Huang JF. Analysis of viral pathogens of children with acute respiratory infection in Tianjin area [Chinese]. Tianjin Med J. 2012;40(6):625-7.

188. Zhang QL, Zhong BC, Tang YM. Analysis of viruses in children with acute respiratory infection in Sanshui area [Chinese]. Lab Medince Clin. 2014; 11(14):1966-70.

189. Lu XM, Li SP, He YJ, Peng Q, Liu SJ. Analysis on detective resutls of multiple respiratory virus antigens in 1256 children [Chinese]. J Appl Clin Pediatr. 2012;27(22):1733-5.

190. Jiang ZM, Peng J, Gu M, Liu JQ, Ji Q. Analysis on pathogens in respiratory infection in 1410 children [Chinese]. Chin J Infect Control. 2013;12(2):129-31.

191. Zhang G, Xia X, Lyu L. Analysis on the detection results of common viruses in 503 children with acute respiratory tract infection [Chinese]. Zhongguo Weishengtaxixue Zazhi Chin J Microecol. 2014;26(10):1206-8.

192. Zhang XQ, Hu J, Ning XX, Gao SF, Wang L. Analysis on the detection situation of 7 common viruses in 2425 children with respiratory tract infection [Chinese]. Lab Med. 2013;28(7):602-5.

193. Fuller JA, Njenga MK, Bigogo G, Aura B, Ope MO, Nderitu L, et al, Association of the $C T$ values of real-time $P C R$ of viral upper respiratory tract infection with clinical severity, Kenya. J Med Virol. 2013;85(5):924-32.

194. Al-Shehri MA, Sadeq A, Quli K. Bronchiolitis in Abha, Southwest Saudi Arabia: viral etiology and predictors for hospital admission. West Afr J Med 2005:24(4):299-304.

195. Mazumdar J, Chawla-Sarkar M, Rajendran K, Ganguly A, Sarkar UK, Ghosh S, et al. Burden of respiratory tract infections among paediatric in and out-patient units during 2010-11. Eur Rev Med Pharmacol Sci. 2013;17(6):802-8.

196. Pratheepamornkull T, Ratanakorn W, Samransamruajkit R, Poovorawan Y. Causative agents of severe community acquired viral pneumonia among children in Eastern Thailand. Southeast Asian J Trop Med Public Health. 2015;46(4):650-6

197. Mlinaric-Galinovic G, Bace A, Cepin-Bogovic J, Ivkovic-Jurekovic I, Sim R, Cosic M. Characteristics of 2006/2007 respiratory syncytial virus outbreak in Zagreb County: proof of predictability of outbreaks periodicity. Paediatr Croat. 2009;53(2):49-52.

198. Xie ZC, Zhang YM. Characteristics of respiratory syncycial virus associated lower respiratory infection in hospitalised children in People's Hospital in Dongguan. Anhui Med Pharm J. 2016;20(1):139-40.

199. Wan C, Yan SN, Zheng G. Clinial features of 112 cases of respiratory syncytial virus associated with lower respiratory infection [Chinese]. Zhejiang Clin Med. 2006:8(4):396-7.

200. Takeyama A, Hashimoto K, Sato M, Sato T, Tomita Y, Maeda R, et al. Clinical and epidemiologic factors related to subsequent wheezing after virusinduced lower respiratory tract infections in hospitalized pediatric patients younger than 3 years. Eur J Pediatr. 2014;173(7):959-66.

201. Ferone EA, Berezin EN, Durigon GS, Finelli C, Felicio MCC, Storni JG, et al. Clinical and epidemiological aspects related to the detection of adenovirus or respiratory syncytial virus in infants hospitalized for acute lower respiratory tract infection. J Pediatr. 2014 Jan;90(1):42-9.

202. Zhu Y, Hua ZY. Clinical and epidemiological features of respiratory syncytial virus penumonia in 182 neonates [Chinese]. J Appl Clin Pediatr. 2011;26(22): 1719-21.

203. Wolf DG, Greenberg D, Kalkstein D, Shemer-Avni Y, Givon-Lavi N, Saleh N, et al. Comparison of human metapneumovirus, respiratory syncytial virus and influenza A virus lower respiratory tract infections in hospitalized young children. Pediatr Infect Dis J. 2006;25(4):320-4.

204. Yu J, Xie Z, Zhang T, Lu Y, Fan H, Yang D, et al. Comparison of the prevalence of respiratory viruses in patients with acute respiratory infections at different hospital settings in North China, 2012-2015. BMC Infect Dis. 2018;18(1):72 Available from: http://www.ezproxy.is.ed.ac.uk/login?url=http:// ovidsp.ovid.com/ovidweb.cgi?T=JS\&CSC=Y\&NEWS=N\&PAGE=fulltext\&D= emexb\&AN=620583565http://openurl.ac.uk/athens:_edu//ffp/LinkFinderPlus/ Display?sid=OVID:Embase\&id=pmid:\&id=10.1186\%2Fs12879-018-2982-3 \&issn $=1471-2334 \&$ isbn $=\&$ volume $=18 \& i s s u e=1 \&$ spage $=\&$ pages $=\&$ date $=201$ $8 \&$ title $=$ BMC+Infectious+Diseases\&atitle $=$ Comparison+of + the + prevalence + of+respiratory+viruses+in+patients+with+acute+respiratory+infections+at+ different+hospital+settings+in+North+China\%2C+2012-2015\&aulast= Yu\&pid=\&.

205. Cao SY, Sun ZX, Chen XF, Cai XH, Yang SY. Detecting result on rspirovirus and chlamydia pneumoniae of pnemonia from nasopharyngeal secretions in infants [Chinese]. Chin J Child Heath Care. 2007;15(4):368-70.
206. Wu YQ. Detection and analysis of the virus in 1200 cases children with acute respiratory tract infection. China J Child Health Care. 2015;23(11): 1216-8.

207. Zhao B, Shen J, Gao Y, Yu X, Zhang X, Wu F. Detection for respiratory viruses in Shanghai with multiplex PCR from 2009 to 2010 [Chinese]. J Hyg Res. 2011:40(5):635-7.

208. Wang YK, Gao WJ, An SH, An HB, Ge SW, Zhang WC. Detection of 7 viral respiratory infection among children. Hebei Med J. 2016;38(14):2229-31.

209. Yoo SJ, Kuak EY, Shin BM. Detection of 12 respiratory viruses with two-set multiplex reverse transcriptase-PCR assay using a dual priming oligonucleotide system. Korean J Lab Med. 2007;27(6):420-7.

210. Parsania M, Poopak B, Pouriayevali MH, Haghighi S, Amirkhani A, Nateghian A. Detection of human Metapneumovirus and Respiratory syncytial virus by realtime polymerase chain reaction among hospitalized young children in Iran. Jundishapur J Microbiol. 2016:9(3):e32974 Available from: http://ovidsp.ovid. com/ovidweb.cgi?T=JS\&CSC $=$ Y\&NEWS=N\&PAGE=fulltext\&D=cagh\&AN=201 63134657http://openurl.ac.uk/athens:_edu//lfp/LinkFinderPlus/Display?sid= OVID:Global+Health\&id=pmid:\&id=\&issn=2008-3645\&isbn=\&volume=9\&issue= 3\&spage=e32974\&pages=e32974\&date=2016\&title=Jundishapur+Journal+of+ Microbiology\&atitle=Detection+of+human+Metapneumovirus+and+Respira tory+syncytial+virus+by+real-time+polymerase+chain+reaction+among+ hospitalized+young+children+in+Iran.\&aulast=Parsania\&pid=\&

211. Chen Q, Shi SY, Hu Z, Zhang QH, Cao X. Detection of Mycoplasm pneumonia, Chlamydia trachomatis and common respiratory viruses in children with acute respiratory infection in Nanjing [Chinese]. Chin J Contemp Pediatr. 2010;12(6):450-4.

212. Calvo C, Pozo F, Garcia-Garcia ML, Sanchez M, Lopez-Valero M, Perez-Brena $P$, et al. Detection of new respiratory viruses in hospitalized infants with bronchiolitis: a three-year prospective study. Acta Paediatr. 2010;99(6):883-7.

213. Tan ZT, Shi L, Lu GX, Xu W, Jia YP, Xing Y, et al. Detection of respiratory syncytial virus in children with respiratory tract infections by nucleic acid amplification fluorogenic quantitative assay [Chinese]. Chin J Contemp Pediatr. 2009;11(10):825-8.

214. Li QH, Gao WJ, Li JY, Shi LA, Hao XJ, Ge SW, et al. Detection of respiratory viruses in children with acute lower respiratory tract infection: an analysis of 5150 children. Chin J Contemp Pediatr. 2016;18(1):51-4.

215. Yang WM, Sun ZH, Zhang SP, Ma HM, Liu CY. Diagnosis of virus in young children with acute lower respiratory infection in Weifang area [Chinese]. Chin J Child Heath Care. 2009;17(2):233-5.

216. Moriyama Y, Hamada H, Okada M, Tsuchiya N, Maru H, Shirato Y, et al. Distinctive clinical features of human bocavirus in children younger than 2 years. Eur J Pediatr. 2010;169(9):1087-92.

217. Dereci S, Cicek AC, Ozkasap S, Mutlu MA, Kocyigit S, Sahin K. Distribution of respiratory viruses which cause lower respiratory tract infection in pediatric age group. J Coast Life Med. 2015:3(7):547-50.

218. Harada Y, Kinoshita F, Yoshida LM, Le Nhat M, Suzuki M, Morimoto K, et al. Does respiratory virus coinfection increases the clinical severity of acute respiratory infection among children infected with respiratory syncytial virus? Pediatr Infect Dis J. 2013 May:32(5):441-5.

219. Mlinaric-Galinovic G, Vilibic-Cavlek T, Ljubin-Sternak S, Drazenovic V, Galinovic I, Tomic $V$, et al. Eleven consecutive years of respiratory syncytial virus outbreaks in Croatia. Pediatr Int. 2009;51(2):237-40.

220. Huang L, Zhou Y, Wang Y. Epidemic characteristics of common virus causing lower respiratory track infection of children from Guiyang area [Chinese]. Matern Child Health Care China. 2013;28(26):4307-9.

221. Qiao RJ, Wang P, Kang Q, Wang XX, Zheng RX, Chen JH, et al. Epidemiological analysis of respiratory syncytial virus in pediatric patients under 5 years in hospital with pneumonia in Baiyin District. Chin J Exp Clin Virol. 2015;29(6):510-4

222. Zuccotti G, Dilillo D, Zappa A, Galli E, Amendola A, Martinelli M, et al. Epidemiological and clinical features of respiratory viral infections in hospitalized children during the circulation of influenza virus A(H1N1) 2009. Influenza Other Respir Viruses. 2011;5(6):e528-34.

223. Lei XY. Epidemiological characteristics of children's respiratory tract viral infection in Chongqing during 2009 and 2011 [Chinese] [Master]. Vol. MSc. Chongqing Medical Univesity; 2012.

224. Zeng M, Wang XH, Yu H, Zhu QR. Epidemiological characteristics of common respiratory viruses among children with acute respiratory tract infection in Shanghai [Chinese]. Chin J Infect Dis. 2008;26(9):527-33.

225. Hu XW, Wang WP. Epidemiological characteristics of respiratory viruses in children of Wuhan [Chinese]. Lab Med Clin. 2014;11(6):770-2. 
226. Park K, Kim D, Seong J, Shin I, Hong J, Park S, et al. Epidemiological features and genetic variation of human respiratory syncytial virus (HRSV) infection in Chungnam, Korea. Biomed Res India. 2017;28(2):967-72.

227. Zhang B, Wang X, Zhang W, Chen XY. Epidemiological features of acute lower respiratory tract viral infections in children [Chinese]. Zhejiang Med J. 2012;34(4):250-5.

228. Xie JH, Hua L, Zhong JY, Zhang YY, Chen Y, Liu XM, et al. Epidemiological features of respiratory syncytial virus infection in Guangzhou children, 2011 to 2013. Chin J Biomed Eng. 2015;21(3):270-5.

229. Hamada H, Ogura A, Hotta C, Wakui T, Ogawa T, Terai M. Epidemiological study of respiratory viruses detected in patients under two years old who required admission because of lower respiratory disease. Kansenshogaku Zasshi - J Jpn Assoc Infect Dis. 2014;88(4):423-9.

230. Sparremberger DAH, Luisi F, Azevedo AV, Ribeiro AET, Munhoz BZ, Conto $B F$, et al.Epidemiological surveillance and influence of co-infection by respiratory virusesin the severity of acute bronchiolitis in infants (Características epidemiológicas e influência da coinfecção por vírus respiratórios na gravidade da bronquiolite aguda em lactentes). Sci Med. 2011;21(3):1. Available from: http://revistaseletronicas.pucrs.br/ojs/index.php/ scientiamedica/article/view/9079/6714php/scientiamedica/article/view/9079/ 6714.

231. Al-Toum R, Bdour S, Ayyash H. Epidemiology and clinical characteristics of respiratory syncytial virus infections in Jordan. J Trop Pediatr. 2006;52(4): 282-7.

232. Loscertales MP, Roca A, Ventura PJ, Abacassamo F, Dos Santos F, Sitaube M, et al. Epidemiology and clinical presentation of respiratory syncytial virus infection in a rural area of southern Mozambique. Pediatr Infect Dis J. 2002; 21(2):148-55.

233. Oliveira DB, Durigon EL, Carvalho AC, Leal AL, Souza TS, Thomazelli LM, et al. Epidemiology and genetic variability of human metapneumovirus during a 4-year-long study in Southeastern Brazil. J Med Virol. 2009;81(5): 915-21.

234. Amer HM, Alshaman MS, Farrag MA, Hamad ME, Alsaadi MM, Almajhdi FN. Epidemiology of 11 respiratory RNA viruses in a cohort of hospitalized children in Riyadh, Saudi Arabia. J Med Virol. 2016;88(6):1086-91.

235. Hervas D, Reina J, Yanez A, del Valle JM, Figuerola J, Hervas JA Epidemiology of hospitalization for acute bronchiolitis in children: differences between RSV and non-RSV bronchiolitis. Eur J Clin Microbiol Infect Dis. 2012;31(8):1975-81.

236. Tsolia MN, Kafetzis D, Danelatou K, Astral H, Kallergi K, Spyridis P, et al. Epidemiology of respiratory syncytial virus bronchiolitis in hospitalized infants in Greece. Eur J Epidemiol. 2003;18(1):55-61.

237. Chen CJ, Jeng MJ, Yuan HC, Wu KG, Soong WJ, Hwang B. Epidemiology of respiratory syncytial virus in children with lower respiratory tract infection. Acta Paediatr Taiwan. 2005:46(2):72-6.

238. Khamis FA, Al-Kobaisi MF, Al-Areimi WS, Al-Kindi H, Al-Zakwani I. Epidemiology of respiratory virus infections among infants and young children admitted to hospital in Oman. J Med Virol. 2012;84(8):1323-9.

239. Van Leeuwen JC, Goossens LK, Hendrix RM, Van Der Palen J, Lusthusz A, Thio BJ. Equal virulence of rhinovirus and respiratory syncytial virus in infants hospitalized for lower respiratory tract infection. Pediatr Infect Dis J. 2012;31(1):84-6.

240. Tallo VL, Kamigaki T, Tan AG, Pamaran RR, Alday PP, Mercado ES, et al. Estimating influenza outpatients' and inpatients' incidences from 2009 to 2011 in a tropical urban setting in the Philippines. Influenza Other Respir Viruses. 2014;8(2):159-68.

241. Ru GP, Li YY, Wang Q, Wang HJ, Zhao WJ. Etiologic analysis of 1200 children less 5 years old with lower respiratory tract infections in Shangzhou City [Chinese]. Hebei Med. 2013;19(8):1243-5.

242. Liu Q, Zhang B, Xie ZP, Zhong LL, Zeng SZ, Liu SP, et al. Etiological analysis of chidlren hospitalised with acute lower respiratory infection in Changsha area [Chinese]. J Hunan Norm Univ. 2015;12(1):26-31.

243. Jiang $M$, Zhao $Y F$, Zhang $Y H$, Zhang $Y Q$, Tang $L X$, Wang JW, et al. Etiological analysis of childen with acute respiratory infection in Nanjing [Chinese]. Chin J Health Lab Technol. 2013;23(4):932-6.

244. Wang D, Yang J, Wang B, Pan LJ, Xiang HJ, Zheng L, et al. Etiological analysis of children with respiratory tract viral infection in Dazu district [Chinese]. Lab Med Clin. 2015;12(10):1364-6.

245. Ferronato AE, Gilio AE, Ferraro AA, Paulis M, Vieira SE. Etiological diagnosis reduces the use of antibiotics in infants with bronchiolitis. Clin Sao Paulo Braz. 2012;67(9):1001-6.
246. Zhao GC, Wang XH, Zhu QR. Etiology and clinical epidemiology of children with acute pneumonia in Shanghai area [Chinese]. Chin J Infect Chemother 2003;3(3):134-7.

247. Ekalaksananan T, Pientong C, Kongyingyoes B, Pairojkul S, Teeratakulpisarn J, Heng S. Etiology of acute lower respiratory tract infection in children at Srinagarind Hospital, Khon Kaen, Thailand. Southeast Asian J Trop Med Public Health. 2001;32(3):513-9.

248. Ji W, Chen ZR, Zhou WF, Sun HM, Li BQ, Cai LH, et al. Etiology of acute respiratory tract infection in hospitalized children Suzhou from 2005 to 2011 [Chinese]. Chin J Prev Med. 2013;47(6):497-503.

249. Sutmoller F, Ferro ZP, Asensi MD, Ferreira V, Mazzei IS, Cunha BL. Etiology of acute respiratory tract infections among children in a combined community and hospital study in Rio de Janeiro. Clin Infect Dis. 1995;20(4):854-60.

250. Chen Y, Lian GW, Zhang YY, Lin T, Deng L, Zhong JY, et al. Etiology of community-acquired pneumonia among pediatric inpatients in Guangzhou during 2012 and 2013 [Chinese]. Chin J Clin Infect Dis. 2014;7(6):521-5.

251. Juven $T$, Mertsola J, Waris M, Leinonen M, Meurman $O$, Roivainen $M$, et al. Etiology of community-acquired pneumonia in 254 hospitalized children. Pediatr Infect Dis J. 2000;19(4):293-8.

252. Qin M, Tian M, Xia W, Wang HY, Shi SY, Chen Q. Etiology of community-acquired pneumonia in children [Chinese]. J Clin Pediatr. 2008;26(4):312-5.

253. Cevey-Macherel M, Galetto-Lacour A, Gervaix A, Siegrist CA, Bille J, BescherNinet $B$, et al. Etiology of community-acquired pneumonia in hospitalized children based on WHO clinical guidelines. Eur J Pediatr. 2009 Dec;168(12): 1429-36.

254. Bedoya VI, Abad V, Trujillo H. Frequency of respiratory syncytial virus in hospitalized infants with lower acute respiratory tract infection in Colombia. Pediatr Infect Dis J. 1996;15(12):1123-4.

255. Faghihloo E, Yavarian J, Jandaghi NZS, Shadab A, Azad TM. Genotype circulation pattern of human respiratory syncytial virus in Iran. Infect Genet Evol. 2014 Mar 1:22:130-3.

256. Zhang G, Hu Y, Wang H, Zhang L, Bao Y, Zhou X. High incidence of multiple viral infections identified in upper respiratory tract infected children under three years of age in Shanghai, China. PLoS ONE Electron Resour. 2012;7(9):e44568.

257. Pavic-Espinoza I, Bendezu-Medina S, Herrera-Alzamora A, Weilg P, Pons MJ, Aguilar-Luis MA, et al. High prevalence of Bordetella pertussis in children under 5 years old hospitalized with acute respiratory infections in Lima, Peru. BMC Infect Dis. 2015;15:554.

258. Singleton RJ, Petersen KM, Berner JE, Schulte E, Chiu K, Lilly CM, et al. Hospitalizations for respiratory syncytial virus infection in Alaska Native children. Pediatr Infect Dis J. 1995;14(1):26-30.

259. Maggi F, Andreoli E, Pifferi M, Meschi S, Rocchi J, Bendinelli M. Human bocavirus in Italian patients with respiratory diseases. J Clin Virol. 2007;38(4):321-5.

260. Teeratakulpisarn J, Ekalaksananan T, Pientong C, Limwattananon C. Human metapneumovirus and respiratory syncytial virus detection in young children with acute bronchiolitis. Asian Pac J Allergy Immunol. 2007;25(2-3): 139-45.

261. Foulongne V, Guyon G, Rodiere M, Segondy M. Human metapneumovirus infection in young children hospitalized with respiratory tract disease. Pediatr Infect Dis J. 2006;25(4):354-9.

262. Miao $Z, X u$ Y, Li P. Human metapneumovirus infection of hospitalized infants in Jiaxing District [Chinese]. Chin J Nosocomiology. 2010;20(24): 3877-9.

263. Salomao JB Jr, Gardinassi LGA, Simas PVM, Bittar CO, Souza FP, Rahal P, et al. Human respiratory syncytial virus in children hospitalized for acute lower respiratory infection [Portuguese] (Virus respiratorio sincicial humano em criancas hospitalizadas por infeccoes agudas das vias aereas inferiores). J Pediatr. 2011 May;87(3):219-24.

264. Kaneko M, Watanabe J, Kuwahara M, Ueno E, Hida M, Kinoshita A, et al. Impact of respiratory syncytial virus infection as a cause of lower respiratory tract infection in children younger than 3 years of age in Japan. J Inf Secur. 2002:44(4):240-3.

265. Noyola DE, Zuviri-Gonzalez A, Castro-Garcia JA, Ochoa-Zavala JR. Impact of respiratory syncytial virus on hospital admissions in children younger than 3 years of age. J Inf Secur. 2007:54(2):180-4.

266. Pecchini $R$, Berezin EN, Felicio MC, Passos SD, Souza MC, Lima LR, et al. Incidence and clinical characteristics of the infection by the respiratory syncytial virus in children admitted in Santa Casa de Sao Paulo Hospital. Braz J Infect Dis. 2008;12(6):476-9. 
267. Oliveira-Santos M, Santos JA, Soares J, Dias A, Quaresma M. Influence of meteorological conditions on RSV infection in Portugal. Int J Biometeorol. 2016;60(12):1807-17

268. Cao XY, Chen WQ, Luo KM, Li GH, Huang HX. Investigation on respiratory syncytial virus infection in children in Qingyuan District from 2012-2014 [Chinese]. Occup Health. 2015;31(10):1.

269. Chen LF, Chen LP. Investigation on respiratory syncytial virus of lower respiratory tract infection in the third liaocheng peoples hospital [Chinese] Chin J Coal Ind Med. 2009;12(11):1678-80.

270. Xiang QW, Luo YC, Chen XF. Investigation on the viral etiology of acute lower respiratory tract infection in Wenzhou Yuying children's hospital [Chinese]. Chin J Pract Pediatr. 2005;20:12.

271. Moura FEA, Ribeiro DH, Borges LC, Ramos EAG. Laboratory diagnosis of acute respiratory infection of viral origin [Portuguese]. Pediatr Mod. 2002; 38(6):255-60.

272. Wasem S, Weichert S, Walther S, Weigl JA, Puppe W, Ihorst G, et al. Lower respiratory tract disease in children: constant pathogens - constant management?! Klin Padiatr. 2008;220(5):291-5.

273. Vieira $\mathrm{SE}$, Gilio $\mathrm{AE}$, Durigon EL, Ejzenberg B. Lower respiratory tract infection caused by respiratory syncytial virus in infants: the role played by specific antibodies. Clin Sao Paulo Braz. 2007;62(6):709-16.

274. Malekshahi SS, Azad TM, Yavarian J, Shahmahmoodi S, Naseri M, Rezaei F. Molecular detection of respiratory viruses in clinical specimens from children with acute respiratory disease in Iran. Pediatr Infect J. 2010;29(10): 931-3 2010/09/30 ed.

275. Tran DN, Pham TM, Ha MT, Tran TT, Dang TK, Yoshida LM, et al. Molecular epidemiology and disease severity of human respiratory syncytial virus in Vietnam. PLoS ONE Electron Resour. 2013;8(1):e45436.

276. Balmaks R, Ribakova I, Gardovska D, Kazaks A. Molecular epidemiology of human respiratory syncytial virus over three consecutive seasons in Latvia. J Med Virol. 2014;86(11):1971-82.

277. Du LN. Molecular epidemiology of respiratory syncytial virus and human metapneumovirus in children in Chongqing area [Chinese] [Master]. Vol. MSc. Chongqing Medical University; 2012

278. Viegas M. Molecular epidemiology of respiratory syncytial virus in pediatric patients in a six-year period. Acta Bioquim Clin Latinoam. 2011 Jan;45(1):3-45

279. Peng Y, Shu C, Fu Z, Li QB, Liu Z, Yan L. Pathogen detection of 1613 cases of hospitalized children with community acquired pneumonia. Chin J Contemp Pediatr. 2015;17(11):1193-9.

280. Xu L, Qiu C, Gong P, Tang J, Deng J. Pathogen spectrum of respiratory viruses in children of Shaoguan, 2010-2012 [Chinese]. J Trop Med. 2014; 14(1):124-6

281. Li LP, Lai Y, Yi SS, SUn KS, Zhu CH. Pathogenic analysis of acute respiratory infections among children in Changsha area [Chinese]. Pract Prev Med. 2013;20(7):876-8

282. Farzin A, Saha SK, Baqui AH, Choi Y, Ahmed NU, Simoes EAF, et al. Population-based incidence and etiology of community-acquired neonatal viral infections in Bangladesh: a community-based and hospital-based surveillance study. Pediatr Infect Dis J. 2015;34(7):706-11.

283. Ma HM, Lee KP, Woo J. Predictors of viral pneumonia: The need for viral testing in all patients hospitalized for nursing home-acquired pneumonia. Geriatr Gerontol Int. 2013 Oct;13(4):949-57.

284. Garcia-Garcia ML, Calvo C, Perez-Brena P, De Cea JM, Acosta B, Casas ।. Prevalence and clinical characteristics of human metapneumovirus infections in hospitalized infants in Spain. Pediatr Pulmonol. 2006:41(9):86371.

285. Vagia F, Makri A, lliadou H, Mammas I, Guajardo T, Nika E, et al. Prevalence and clinical features of respiratory syncytial virus and human metapneumovirus lower respiratory disease among children in Greece. Clin Microbiol Infect. 2010 Apr;16:S428-9.

286. Lamarao LM, Ramos FL, Mello WA, Santos MC, Barbagelata LS, Justino MC, et al. Prevalence and clinical features of respiratory syncytial virus in children hospitalized for community-acquired pneumonia in northern Brazil. BMC Infect Dis. 2012;12(1):119.

287. Wang H, Zheng Y, Deng J, Wang W, Liu P, Yang F, et al. Prevalence of respiratory viruses among children hospitalized from respiratory infections in Shenzhen, China. Virol J. 2016;13:39 Available from: http://ovidsp.ovid. com/ovidweb.cgi? T=JS\&CSC $=$ Y\&NEWS=N\&PAGE=fulltext\&D=cagh\&AN=20 $63116911 \mathrm{http} / / /$ openurl.ac.uk/athens:_edu//Ifp/LinkFinderPlus/Display?sid= OVID:Global+Health\&id=pmid:\&id=\&issn=1743-422x\&isbn=\&volume $=13$ \&issue $=39 \&$ spage $=\&$ pages $=\% 288+$ March $+2016 \% 29 \&$ date $=2016 \&$ title $=$
Virology+Journal\&atitle=Prevalence+of+respiratory+viruses+among+ children+hospitalized+from+respiratory+infections+in+Shenzhen\%2C+ China.\&aulast=\&pid=\&.

288. Chung JY, Han TH, Kim SW, Hwang ES. Respiratory picornavirus infections in Korean children with lower respiratory tract infections. Scand J Infect Dis. 2007:39(3):250-4.

289. Chan DCW, Chiu WK, Ip PLS. Respiratory syncytial virus and influenza infections among children $<3$ years of age with acute respiratory infections in a regional hospital in Hong Kong. Hong Kong J Paediatr. 2007;12(1):1562.

290. Moyes J, Walaza S, Pretorius M, Groome M, von Gottberg A, Wolter N, et al. Respiratory syncytial virus in adults with severe acute respiratory illness in a high HIV prevalence setting. J Inf Secur. 2017 Oct;75(4):346-55.

291. Pineros JG, Baquero H, Bastidas J, Garcia J, Ovalle O, Patino CM, et al. Respiratory syncytial virus infection as a cause of hospitalization in population under 1 year in Colombia. J Pediatr. 2013;89(6):544-8.

292. Hussey GD, Apolles P, Arendse Z, Yeates J, Robertson A, Swingler G, et al. Respiratory syncytial virus infection in children hospitalised with acute lower respiratory tract infection. S Afr Med J. 2000;90(5):509-12.

293. Macedo SEC, Menezes AMB, Post P, Albernaz E, Knorst M. Respiratory syncytial virus infection in children under one year of age hospitalized for acute respiratory diseases in Pelotas, RS. J Pneumol. 2003;29(1):4-8.

294. Dowell SF, Anderson LJ, Gary HE Jr, Erdman DD, Plouffe JF, File TM Jr, et al. Respiratory syncytial virus is an important cause of community-acquired lower respiratory infection among hospitalized adults. J Infect Dis. 1996 Sep; 174(3):456-62.

295. Bdour S. Respiratory syncytial virus subgroup A in hospitalized children in Zarqa, Jordan. Ann Trop Paediatr. 2001;21(3):253-61.

296. Flaherman V, Li S, Ragins A, Masaquel A, Kipnis P, Escobar GJ. Respiratory syncytial virus testing during bronchiolitis episodes of care in an integrated health care delivery system: a retrospective cohort study. Clin Ther. 2010; 32(13):2220-9.

297. Carballal G, Videla C, Sequeira MD, Mistchenko A, Requeijo PV, Arbiza J. Respiratory syncytial virus: changes in prevalence of subgroups $A$ and $B$ among Argentinian children, 1990-1996. J Med Virol. 2000;61(2):275-9.

298. Assaf-Casals A, Ghanem S, Rajab M. Respiratory syncytial virus: prevalence and features among hospitalized Lebanese children. Br J Med Med Res. 2015;6(1):77-87.

299. Turner P, Turner C, Watthanaworawit W, Carrara V, Cicelia N, Deglise C, et al. Respiratory virus surveillance in hospitalised pneumonia patients on the Thailand-Myanmar border. BMC Infect Dis. 2013;13(1):434.

300. Yeolekar LR, Damle RG, Kamat AN, Khude MR, Simha V, Pandit AN. Respiratory viruses in acute respiratory tract infections in Western India. Indian J Pediatr. 2008;75(4):341-5.

301. Zhang AL, Wu M, Zhang $X, W u X Y$. Results of common virus test in hospitalised children [Chinese]. Zhejiang Prev Med. 2013;25(4):62-4

302. Hu J, Zhao K, Zhu T. Retrospective study of viral etiology of acute lower respiratory tract infections in hospitalised children in Suzhou Area. Heilongjiang Med J. 2015;39(10):1122-3.

303. Banerji A, Greenberg D, White LF, Macdonald WA, Saxton A, Thomas E, et al. Risk factors and viruses associated with hospitalization due to lower respiratory tract infections in Canadian Inuit children : a case-control study. Pediatr Infect Dis J. 2009;28(8):697-701.

304. Murray J, Bottle A, Sharland M, Modi N, Aylin P, Majeed A, et al. Risk factors for hospital admission with RSV bronchiolitis in England: a population-based birth cohort study. PLoS One. 2014;9(2):e89186 Available from: http://ovidsp.ovid. com/ovidweb.cgi?T=JS\&CSC $=$ Y\&NEWS=N\&PAGE=fulltext\&D=cagh\&AN= 20143167784http://openurl.ac.uk/athens:_edu//lfp/LinkFinderPlus/Display?sid= OVID:Global+Health\&id=pmid:\&id=10.1371\%2Fjournal.pone.0089186\&issn= 1932-6203\&isbn $=\&$ volume $=9 \&$ issue $=2 \&$ spage $=e 89186 \&$ pages $=e 89186 \&$ date $=$ 2014\&title=PLoS+ONE\&atitle=Risk+factors+for+hospital+admission+with+ RSV+bronchiolitis+in+England\%3A+a+population-based+birth+cohort+study. \&aulast=Murray\&pid=\&http://www.plosone.org/article/fetchObject.action?uri= info:doi/10.1371/journal.pone.0089186\&representation=PDF.

305. Garcia CG, Bhore R, Soriano-Fallas A, Trost M, Chason R, Ramilo O, et al. Risk factors in children hospitalized with RSV bronchiolitis versus non-RSV bronchiolitis. Pediatrics. 2010;126(6):e1453-60.

306. Nascimento-Carvalho CM, Cardoso MR, Barral A, Araujo-Neto CA, Oliveira JR, Sobral LS, et al. Seasonal patterns of viral and bacterial infections among children hospitalized with community-acquired pneumonia in a tropical region. Scand J Infect Dis. 2010;42(11-12):839-44. 
307. Weigl JA, Puppe W, Schmitt HJ. Seasonality of respiratory syncytial viruspositive hospitalizations in children in Kiel, Germany, over a 7-year period. Infection. 2002;30(4):186-92.

308. Zhang Y, Sakthivel SK, Bramley A, Jain S, Haynes A, Chappell JD, et al. Serology enhances molecular diagnosis of respiratory virus infections other than influenza in children and adults hospitalized with community-acquired pneumonia. J Clin Microbiol. 2017;55(1):79-89.

309. Jansson L, Nilsson P, Olsson M. Socioeconomic environmental factors and hospitalization for acute bronchiolitis during infancy. Acta Paediatr. 2002 91(3):335-8.

310. Liu XT, Wang GL, Luo XF, Chen YL, Ou JB, Huang J, et al. Spectrum of pathogens for community-acquired pneumonia in children [Chinese]. Chin J Contemp Pediatr. 2013;15(1):42-5.

311. Jiang JP, Lan YL. Study of respiratory syncytial virus pneumonia in neonate [Chinese]. Mod J Integr Tradit Chin West Med. 2007;16(14):1892-3.

312. Sun LX, Huang JF, Zhang H. Study of viral pathogens from children with lower respiratory infection in Tianjin [Chinese]. China J Mod Med. 2004; 14(24):129-30

313. Ma XL, Xu YC, Zheng JY, Chen XJ. Study on pathogen and clinical characteristics of infectious pneumonia in neonates [Chinese]. Zhejiang Prev Med. 2005;17(1):6-8

314. Xie F, Cai YY, Yang L, Yue B. Study on viral pathogen of acute respiratory infection of 741 children. China J Child Health Care. 2015;23(2):1104-6.

315. Chen J. Study on viral pathogen of bronchiolitis in two hundred and six infants [Chinese] [Master]. Vol. MSc. Shandong University; 2012.

316. Zhang YM, Feng YZ, Luo SZ, Lei CL. Study on viral pathogens of lower respiratory infection in young children [Chinese]. Shanxi Med J. 2002;31(3): 195-7.

317. Chen $H$, Dong L. Surveilance of common viruse causing acute respiratory infection in hospitalised children in Wenzhou city. Zhejiang Prev Med. 2015; 27(11):1134-6.

318. Avendano LF, Palomino MA, Larranaga C. Surveillance for respiratory syncytial virus in infants hospitalized for acute lower respiratory infection in Chile (1989 to 2000). J Clin Microbiol. 2003:41(10):4879-82.

319. Peng DH, Liu EM, Zhao XD, Huang Y, Liu Y, Luo XJ. Surveillance for respiratory viruses in children with acute lower respiratory infections in Chongqing between 2003 and 2007 [Chinese]. J Appl Clin Pediatr. 2009; 24(10):768-70.

320. Wansaula Z, Olsen SJ, Casal MG, Golenko C, Erhart LM, Kammerer P, et al. Surveillance for severe acute respiratory infections in Southern Arizona, 2010-2014. Influenza Other Respir Viruses. 2016 May;10(3):161-9.

321. Cao Y, Zhang M, Liao H, Guan H, Ye Q, Pei X, et al. Surveillance on 592 cases of human respiratory syncytial virus infection in hospitalized children with respiratory tract infection in Sichuan [Chinese]. Mod Prev Med. 2013; 40(7):1249-51.

322. Sheng $\mathrm{KH}$, Xu MY, Sun BL, Huang ZH. The aetiological analysis of common viruses of acute lower respiratory infection among the hospitalised children 0 to 7 years old in Nantong of Jiangsu [Chinese]. Chin J Prim Med Pharm. 2014;21(11):1607-9.

323. Lu M, Zeng M, Lu Q, Gu LQ. The epidemiologic feature of viral infection in the children with acute lower respiratory tract infections in Shanghai [Chinese]. Chin J Infect Chemother. 2005;5(3):152-5.

324. Turkish Neonatal S. The seasonal variations of respiratory syncytial virus infections in Turkey: a 2-year epidemiological study. Turk J Pediatr. 2012; 54(3):216-22.

325. Yin F. The viral epidemiology and the analysis of clinical features of human bocavirus in children with acute respiratory tract infection in Sochow area [Chinese] [Master]. Vol. MSc. Soochow University; 2014

326. Canducci F, Debiaggi M, Sampaolo M, Marinozzi MC, Berre S, Terulla C, et al. Two-year prospective study of single infections and co-infections by respiratory syncytial virus and viruses identified recently in infants with acute respiratory disease. J Med Virol. 2008:80(4):716-23.

327. Bakir TM, Halawani M, Ramia S. Viral aetiology and epidemiology of acute respiratory infections in hospitalized Saudi children. J Trop Pediatr. 1998. 44(2):100-3

328. Lu Y, Tong J, Pei F, Yang Y, Xu D, Ji M, et al. Viral aetiology in adults with acute upper respiratory tract infection in Jinan, Northern China. Clin Dev Immunol. 2013;2013:869521.

329. Chan PW, Goh AY, Chua KB, Kharullah NS, Hooi PS. Viral aetiology of lower respiratory tract infection in young Malaysian children. J Paediatr Child Health. 1999;35(3):287-90.
330. Bukhari EE, Elhazmi MM. Viral agents causing acute lower respiratory tract infections in hospitalized children at a tertiary care center in Saudi Arabia. Saudi Med J. 2013;34(11):1151-5.

331. Wertheim HFL, Nadjm B, Thomas S, Agustiningsih MS, DNT N, et al. Viral and atypical bacterial aetiologies of infection in hospitalised patients admitted with clinical suspicion of influenza in Thailand, Vietnam and Indonesia. Influenza Other Respir Viruses. 2015;9(6):315-22.

332. Do AH, van Doorn HR, Nghiem MN, Bryant JE, Hoang TH, Do QH, et al. Viral etiologies of acute respiratory infections among hospitalized Vietnamese children in Ho Chi Minh City, 2004-2008. PLoS ONE Electron Resour. 2011; 6(3):e18176.

333. Zhang Q, Guo Z, MacDonald NE. Vaccine preventable community-acquired pneumonia in hospitalized children in Northwest China. Pediatr Infect Dis J. 2011;30(1):7-10.

334. Ding XF, Zhang B, Zhong LL, Xiao MG, Zhou QH, Duan ZJ, et al. Viral etiology and risk factors for severe community-acquired pneumonia in children [Chinese]. J Clin Pediatr. 2012;30(9):857-61.

335. Lin ZB, Li LQ, Chen QH, Zheng JY, Fu QL. Viral etiology investigation of children community acquired pneumonia in Quanzhou area [Chinese]. Chin Community Dr. 2015;31(4):102-5.

336. Xiao NG, Zhang B, Duan ZJ, Xie ZP, Zhou QH, Zhong LL, et al. Viral etiology of 1165 hospitalized children with acute lower respiratory tract infection [Chinese]. Chin J Contemp Pediatr. 2012;14(1):28-32.

337. Suryadevara M, Cummings E, Bonville CA, Bartholoma N, Riddell S, Kiska D, et al. Viral etiology of acute febrile respiratory illnesses in hospitalized children younger than 24 months. Clin Pediatr (Phila). 2011;50(6):513-7.

338. Pourakbari B, Mahmoudi S, Movahedi Z, Halimi S, Momeni S, HosseinpourSadeghi $R$, et al. Viral etiology of acute lower respiratory tract infections in hospitalized young children in a children's referral hospital in Iran. Turk J Pediatr. 2014:56(4):354-9.

339. Chang J, Li CY, Li HJ, Luo YC, Chen XF, Yang SY. Viral etiology of acute respiratory infection in children from Wenzhou between 2007 and 2008 [Chinese]. Chin J Contemp Pediatr. 2010;12(1):32-4.

340. Huang G, Yu D, Mao N, Zhu Z, Zhang H, Jiang Z, et al. Viral Etiology of Acute Respiratory Infection in Gansu Province, China, 2011. Jin D-Y, editor. PLoS ONE. 2013;8(5):e64254.

341. Liu CY, Xiao Y, Xie ZD, Ren LL, Hu YH, Yao Y, et al. Viral etiology of acute respiratory tract infection among pediatric inpatients and outpatients from 2010 to 2012 in Beijing, China [Chinese]. Chin J Pediatr. 2013;51(4):255-9.

342. Liu T, Li Z, Zhang S, Song S, Julong W, Lin Y, et al. Viral Etiology of acute respiratory tract infections in hospitalized children and adults in Shandong Province, China. Virol J. 2015:12:168.

343. Chen YW, Huang YC, Ho TH, Huang CG, Tsao KC, Lin TY. Viral etiology of bronchiolitis among pediatric inpatients in northern Taiwan with emphasis on newly identified respiratory viruses. J Microbiol Immunol Infect. 2014; 47(2):116-21.

344. Ju HX, Zhou ZW, Zhu R, Tang JF. Viral etiology of hospitalized children with acute respiratory tract infection [Chinese]. J Jiangsu Univ. 2012;22(6):494-6.

345. Kenmoe S, Tchendjou P, Vernet MA, Moyo-Tetang S, Mossus T, NjankouoRipa $M$, et al. Viral etiology of severe acute respiratory infections in hospitalized children in Cameroon, 2011-2013. Influenza Other Respir Viruses. 2016;10(5):386-93.

346. Tang LF, Wang TL, Tang HF, Chen ZM. Viral pathogens of acute lower respiratory tract infection in China. Indian Pediatr. 2008;45(12):971-5.

347. Ou SY, Lin GY, Wu Y, Lu XD, Lin CX, Zhou RB. Viral pathogens of acute lower respiratory tract infection in hospitalized children from East Guangdong of China [Chinese]. Chin J Contemp Pediatr. 2009;11(3):203-6.

348. 李琳, 刘晨，王红阳. 不同时期老年社区获得性肺炎患者不典型病原检测 结果分析. 实用老年医学. 2012;(05):412-4.

349. 高䵢, 魏少军, 何宝明, 李艳琴, 张玲. 住院患者鼻咽灌洗液标本中呼吸道 感染病毒检测及耐药性分析. Shaojun WEl, Baoming HE, Yanqin LI, Ling Z, editors. 检验医学与临床. 2017:(24):3615-7.

350. 马文瑛, 张慧, 姜中毅, 李红育, 苗砚迪, 段莉平, et al. 兰州市2009-2013年 住院病例中严重急性呼吸道感染病毒病原学监测研究. 中国病毒病杂志 2015;(04):281-6.

351. 刘信荣，王红阳，李琳. 成人急性呼吸道感染住院病人病毒 $\lg M$ 抗体检测 结果分析. 医学临床研究. 2004;(08):879-82.

352. 李月越, 王萍, 陈杭薇, 赵雅辉. 病毒及非典型病原体致社区获得性肺炎 住院患者的临床分析. 临床肺科杂志. 2017;(02):279-83.

353. 程勇, 薛晓婕. 老年呼吸道感染患者9项呼吸道病原体感染状况分析. 实 用老年医学. 2015;(05):409-11. 
354. Zheng P, Barber R, Sorensen RJD, Murray CJL, Aravkin AY. Trimmed Constrained Mixed Effects Models: Formulations and Algorithms. ArXiv190910700 Math Stat [Internet]. 2020 Oct 27 [cited 2021 Jan 22]; Available from: http://arxiv.org/abs/1909.10700

355. Zheng P. zhengp0/limetr [Internet]. 2021 [cited 2021 Jan 22]. Available from: https://github.com/zhengp0/limetr.

356. Mortality, morbidity, and hospitalisations due to influenza lower respiratory tract infections, 2017: an analysis for the Global Burden of Disease Study 2017. Lancet Respir Med. 2019;7(1):69-89.

357. Matias G, Taylor R, Haguinet F, Schuck-Paim C, Lustig R, Shinde V. Estimates of hospitalization attributable to influenza and RSV in the US during 19972009, by age and risk status. BMC Public Health. 2017;17(1):271.

358. Matias G, Taylor RJ, Haguinet F, Schuck-Paim C, Lustig RL, Fleming DM. Modelling estimates of age-specific influenza-related hospitalisation and mortality in the United Kingdom. BMC Public Health. 2016;16:1 [cited 2020 Apr 28] Available from: https://www.ncbi.nlm.nih.gov/pmc/articles/PMC4 898386/.

359. Thompson WW, Shay DK, Weintraub E, Brammer L, Bridges CB, Cox NJ, et al. Influenza-Associated Hospitalizations in the United States. JAMA. 2004; 292(11):1333-40

360. Schanzer DL, McGeer A, Morris K. Statistical estimates of respiratory admissions attributable to seasonal and pandemic influenza for Canada. Influenza Other Respir Viruses. 2013;7(5):799-808.

361. Shi T, McAllister DA, O'Brien KL, Simoes EAF, Madhi SA, Gessner BD, et al. Global, regional, and national disease burden estimates of acute lower respiratory infections due to respiratory syncytial virus in young children in 2015: a systematic review and modelling study. Lancet. 2017;390(10098): 946-58

362. Reeves RM, Hardelid P, Gilbert R, Warburton F, Ellis J, Pebody RG. Estimating the burden of respiratory syncytial virus (RSV) on respiratory hospital admissions in children less than five years of age in England, 2007-2012. Influenza Other Respir Viruses. 2017;11(2):122-9.

363. Wu P, Presanis AM, Bond HS, Lau EHY, Fang VJ, Cowling BJ. A joint analysis of influenza-associated hospitalizations and mortality in Hong Kong, 19982013. Sci Rep. 2017 20;7(1):929.

364. Reed C, Chaves SS, Kirley PD, Emerson R, Aragon D, Hancock EB, et al. Estimating influenza disease burden from population-based surveillance data in the United States. PLoS One. 2015;10(3):e0118369.

365. Kyeyagalire R, Tempia S, Cohen AL, Smith AD, McAnerney JM, DermauxMsimang $V$, et al. Hospitalizations associated with influenza and respiratory syncytial virus among patients attending a network of private hospitals in South Africa, 2007-2012. BMC Infect Dis. 2014;14:694

366. Austria Hospital Inpatient Discharges | GHDx. [cited 2020 Mar 6]. Available from: http://ghdx.healthdata.org/series/austria-hospital-inpatient-discharges

367. Botswana Health Management Data System (HMDS) | GHDx [Internet] [cited 2020 Mar 6]. Available from: http://ghdx.healthdata.org/series/botswa na-health-management-data-system-hmds

368. Brazil Hospital Information System (SIH) | GHDx. [cited 2020 Mar 6]. Available from: http://ghdx.healthdata.org/series/brazil-hospital-information-system-sih

369. Li Y. National burden estimates of hospitalisations for acute lower respiratory infections due to respiratory syncytial virus in 2020: the Burden of Influenza and RSV Disease (BIRD) study. University of Edinburgh. College of Medicine \& Veterinary Medicine. Lancet Respir Med. 2020;9(2):17 [cited 2020 Jun 3]. Available from: https://datashare.is.ed.ac.uk/handle/10283/3611.

370. Chile Hospital Discharge Information System / GHDx. [cited 2020 Mar 6]. Available from: http://ghdx.healthdata.org/series/chile-hospital-dischargeinformation-system

371. China Hospital Inpatient Discharges 2013 | GHDx. [cited 2020 Mar 6]. Available from: http://ghdx.healthdata.org/record/china-hospital-inpatientdischarges-2013

372. Ecuador Statistical Registry of Hospital Beds and Discharges / GHDx. [cited 2020 Mar 6]. Available from: http://ghdx.healthdata.org/series/ecuador-sta tistical-registry-hospital-beds-and-discharges

373. European Hospital Morbidity Database /GHDx. [cited 2020 Mar 6]. Available from: http://ghdx.healthdata.org/series/european-hospital-morbidity-database

374. Germany Hospital Statistics Reporting System / GHDx. [cited 2020 Mar 6] Available from: http://ghdx.healthdata.org/series/germany-hospital-statisticsreporting-system

375. India - Mysore JSS Hospital Inpatient Data 2014 | GHDx. [cited 2020 Mar 6]. Available from: http://ghdx.healthdata.org/record/india-mysore-jss-hospitalinpatient-data-2014
376. India - Shillong Nazareth Hospital Inpatient Discharges 2014 | GHDx. [cited 2020 Mar 6]. Available from: http://ghdx.healthdata.org/record/indiashillong-nazareth-hospital-inpatient-discharges-2014

377. Iran Hospital Data 2001-2010 | GHDx. [cited 2020 Mar 6]. Available from: http://internal-ghdx.healthdata.org/record/iran-hospital-data-2001-2010

378. Italy Hospital Inpatient Discharges 2016 | GHDx. [cited 2020 Mar 6]. Available from: http://internal-ghdx.healthdata.org/record/italy-hospital-inpa tient-discharges-2016

379. Japan Diagnosis Procedure Combination Database 2015 | GHDx. [cited 2020 Mar 6]. Available from: http://ghdx.healthdata.org/record/japan-diagnosisprocedure-combination-database-2015

380. Jordan Al-Bashir Hospital Discharges 2016 | GHDx. [cited 2020 Mar 6]. Available from: http://internal-ghdx.healthdata.org/record/jordan-al-bashirhospital-discharges-2016

381. Kenya National Inpatient Morbidity and Mortality Statistics 1999 | GHDx. [cited 2020 Mar 6]. Available from: http://internal-ghdx.healthdata.org/ record/kenya-national-inpatient-morbidity-and-mortality-statistics-1999

382. Mexico Automated Hospital Discharge System (SAEH) | GHDx. [cited 2020 Mar 6]. Available from: http://ghdx.healthdata.org/series/mexico-automatedhospital-discharge-system-saeh

383. Nepal Hospital Inpatient Discharges | GHDx. [cited 2020 Mar 6]. Available from: http://ghdx.healthdata.org/series/nepal-hospital-inpatient-discharges

384. New Zealand National Minimum Dataset Records / GHDx. [cited 2020 Mar 6]. Available from: http://ghdx.healthdata.org/series/new-zealand-nationalminimum-dataset

385. Global Burden of Disease Study 2017 (GBD 2017) Data Input Sources Tool | GHDx. [cited 2020 Jun 3]. Available from: http://ghdx.healthdata.org/gbd-2 017/data-input-sources

386. Norway Patient Register Dataset Records | GHDx. [cited 2020 Mar 6]. Available from: http://ghdx.healthdata.org/series/norway-patient-register

387. Philippine Health Insurance Corporation Claims 2014 | GHDx. [cited 2020 Mar 6]. Available from: http://ghdx.healthdata.org/record/philippine-healthinsurance-corporation-claims-2014

388. Portugal Hospital Inpatient Discharges 2015 | GHDx. [cited 2020 Mar 6]. Available from: http://ghdx.healthdata.org/record/portugal-hospital-inpa tient-discharges-2015

389. Qatar - Annual Inpatients Discharge Abstract: Hamad General Hospital 2002 | GHDx. [cited 2020 Mar 6]. Available from: http://ghdx.healthdata.org/ record/qatar-annual-inpatients-discharge-abstract-hamad-general-hospital-2 002

390. Sweden National Patient Register | GHDx. [cited 2020 Mar 6]. Available from: http://ghdx.healthdata.org/series/sweden-national-patient-register

\section{Publisher's Note}

Springer Nature remains neutral with regard to jurisdictional claims in published maps and institutional affiliations.

Ready to submit your research? Choose BMC and benefit from

- fast, convenient online submission

- thorough peer review by experienced researchers in your field

- rapid publication on acceptance

- support for research data, including large and complex data types

- gold Open Access which fosters wider collaboration and increased citations

- maximum visibility for your research: over $100 \mathrm{M}$ website views per year

At $\mathrm{BMC}$, research is always in progress.

Learn more biomedcentral.com/submission 